2016

\title{
Ceramic Vessels from Caddo Sites in Wood County, Texas
}

Timothy K. Perttula

Heritage Research Center, Stephen F. Austin State University

Mark Walters

Heritage Research Center, Stephen F. Austin State University

Follow this and additional works at: https://scholarworks.sfasu.edu/ita

Part of the American Material Culture Commons, Archaeological Anthropology Commons, Environmental Studies Commons, Other American Studies Commons, Other Arts and Humanities Commons, Other History of Art, Architecture, and Archaeology Commons, and the United States History Commons

Tell us how this article helped you.

This Article is brought to you for free and open access by the Center for Regional Heritage Research at SFA ScholarWorks. It has been accepted for inclusion in Index of Texas Archaeology: Open Access Gray Literature from the Lone Star State by an authorized editor of SFA ScholarWorks. For more information, please contact cdsscholarworks@sfasu.edu. 


\section{Ceramic Vessels from Caddo Sites in Wood County, Texas}

Creative Commons License

(c) (i) (8)

This work is licensed under a Creative Commons Attribution-NonCommercial 4.0 International License 


\title{
Ceramic Vessels from Caddo Sites in Wood County, Texas
}

\author{
Timothy K. Perttula and Mark Walters
}

\section{INTRODUCTION}

This article concerns the documentation of 54 ceramic vessels in the collections of the Texas Archeological Research Laboratory at The University of Texas at Austin (TARL) from seven ancestral Caddo sites in Wood County in East Texas (Figure 1). This includes vessels from A. C. Gibson (41WD1, n=2 vessels), J. H. Reese (41WD2, n=26), H. D. Spigner (41WD4, n=17), Mattie Dial (41WD5, n=2), B. F. Cathey (41WD14, n=2), J. H. Baker (41WD33, $n=4)$, and 41WD117 ( $\mathrm{n}=1$ vessel).

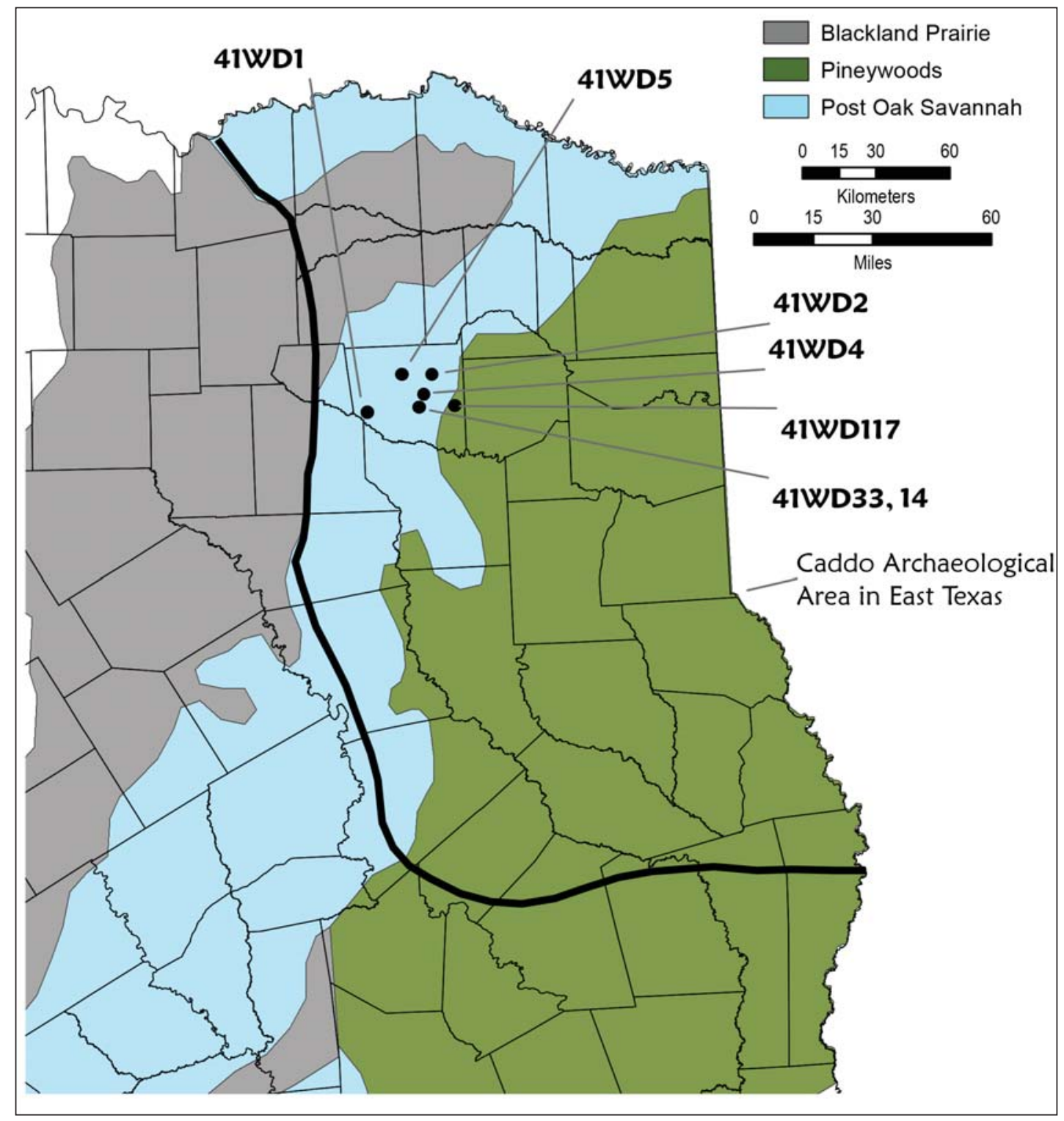

Figure 1. Location of Wood County, Texas, sites mentioned in the text. 
The A. C. Gibson site is situated in the floodplain of the Sabine River near the confluence with Cottonwood Creek. In 1932, looters had dig in a midden deposit (with many mussel shells) and exposed one ancestral Caddo burial with two vessels. In 1934, University of Texas archaeologists excavated two more burials (S-1 and S-2) in the midden. Burial S-1 was that of a child, in a flexed position; this burial had no associated funerary offerings. Burial S-2 held two individuals in an extended supine position in an east-west oriented grave. This burial had two ceramic vessels and a rounded elbow pipe as funerary offerings (Jackson 1934).

The TARL files also indicate that at least three ancestral Caddo burials were excavated by amateur archaeologists prior to the 1970s, and at least one burial had associated ceramic vessels. The nearby Son Gibson Farm site (41WD518) is reported to have had sherds from Sanders Slipped, Sanders Engraved, Canton Incised, and Maxey Noded Redware vessels, and it may be contemporaneous with the burials at the A. C. Gibson site.

SITE NAME OR SITE NUMBER: A. C. Gibson

VESSEL NO.: 4, Burial S-2

VESSEL FORM: Bowl

NON-PLASTICS AND PASTE: grog

RIM AND LIP FORM: Direct rim and rounded, exterior folded lip

CORE COLOR: $\mathrm{F}$ (fired in a reducing environment and cooled in the open air)

INTERIOR SURFACE COLOR: red

EXTERIOR SURFACE COLOR: red

WALL THICKNESS (IN MM): rim, $6.0 \mathrm{~mm}$; body, $7.1 \mathrm{~mm}$

INTERIOR SURFACE TREATMENT: smoothed

EXTERIOR SURFACE TREATMENT: burnished

HEIGHT (IN CM): 12.1

ORIFICE DIAMETER (IN CM): 15.4

DIAMETER AT BOTTOM OF RIM OR NECK (IN CM): N/A

BASE DIAMETER (IN CM) AND SHAPE OF BASE: 8.3; circular and flat

ESTIMATED VOLUME (IN LITERS): 1.5

DECORATION (INCLUDING MOTIF AND ELEMENTS WHEN APPARENT): The interior and exterior vessel surfaces (except for the exterior base) have a red slip.

PIGMENT USE AND LOCATION ON VESSEL: none

TYPE AND VARIETY (IF KNOWN): Sanders Slipped 
SITE NAME OR SITE NUMBER: A. C. Gibson

VESSEL NO.: 5 (28+ sherds, including conjoined lower body and base section)

VESSEL FORM: Jar with two lip tabs

NON-PLASTICS AND PASTE: grog

RIM AND LIP FORM: Everted rim and rounded lip

CORE COLOR: F (fired in a reducing environment and cooled in the open air)

INTERIOR SURFACE COLOR: yellowish-brown

EXTERIOR SURFACE COLOR: yellowish-brown; fire clouds on the body

WALL THICKNESS (IN MM): rim, $5.8 \mathrm{~mm}$; body, $6.0 \mathrm{~mm}$; base, $9.7 \mathrm{~mm}$

INTERIOR SURFACE TREATMENT: none

EXTERIOR SURFACE TREATMENT: smoothed on the lower body

HEIGHT (IN CM): N/A

ORIFICE DIAMETER (IN CM): 13.0

DIAMETER AT BOTTOM OF RIM OR NECK (IN CM): 12.8

BASE DIAMETER (IN CM) AND SHAPE OF BASE: N/A

ESTIMATED VOLUME (IN LITERS): N/A

DECORATION (INCLUDING MOTIF AND ELEMENTS WHEN APPARENT): Plain

PIGMENT USE AND LOCATION ON VESSEL: none

TYPE AND VARIETY (IF KNOWN): Unidentified plain ware 


\section{J. H. Reese Site (41WD2) Vessel Documentation}

The J. H. Reese site (41WD2) is an ancestral Caddo habitation area and small cemetery in the Little Dry Creek valley in the upper Sabine River basin, not far from the Burks site (41WD52), a $15^{\text {th }}$ to early $16^{\text {th }}$ century A.D. Titus phase settlement and cemetery (Perttula 2005). University of Texas archaeologists excavated three burials at the site in 1930; each burial had associated ceramic vessel funerary offerings.

SITE NAME OR SITE NUMBER: J. H. Reese

VESSEL NO.: 1, Burial 1

VESSEL FORM: Carinated bowl

NON-PLASTICS AND PASTE: grog

RIM AND LIP FORM: Direct rim and rounded, exterior folded lip

CORE COLOR: B (fired and cooled in a reducing environment)

INTERIOR SURFACE COLOR: very dark grayish-brown

EXTERIOR SURFACE COLOR: very dark grayish-brown; fire clouds on the body

WALL THICKNESS (IN MM): rim, $7.0 \mathrm{~mm}$

INTERIOR SURFACE TREATMENT: burnished

EXTERIOR SURFACE TREATMENT: burnished

HEIGHT (IN CM): 14.0

ORIFICE DIAMETER (IN CM): 27.4

DIAMETER AT BOTTOM OF RIM OR NECK (IN CM): 27.2

BASE DIAMETER (IN CM) AND SHAPE

OF BASE: 8.2; circular and flat

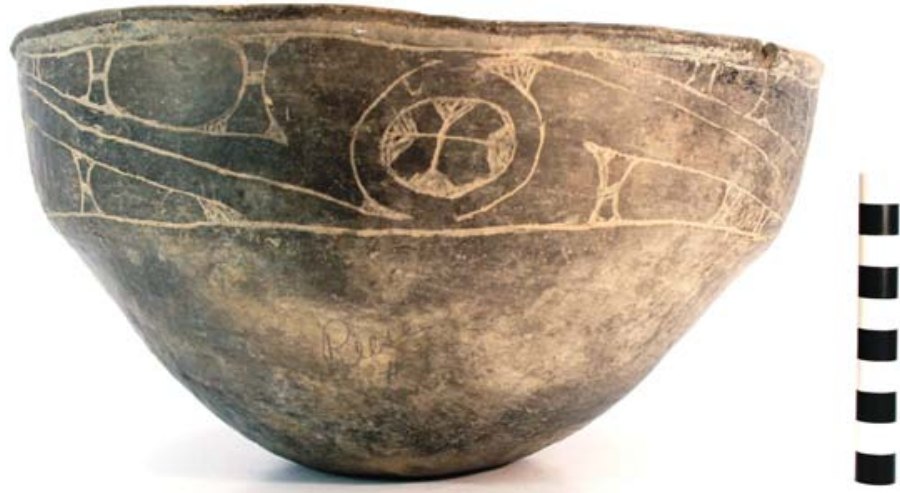

Figure 2. Ripley Engraved, var. Galt carinated bowl from ESTIMATED VOLUME(IN LITERS): 3.5

Burial 1 at the J. H. Reese site (41WD2).

DECORATION (INCLUDING MOTIF AND ELEMENTS WHEN APPARENT): The rim has an engraved scroll and circle motif repeated four times around the vessel. The central circle has semi-circular lines on either side, and these have either hatched or excised triangular elements at their top or bottom; the circle itself has two equal arm horizontal and vertical engraved lines with hatched or excised pendant triangles at the top of the lines. The upper and lower scroll fill zones have brackets with hatched lines, small excised triangle elements in their corners, and excised triangle elements (Figure 2).

PIGMENT USE AND LOCATION ON VESSEL: none

TYPE AND VARIETY (IF KNOWN): Ripley Engraved, var. Galt 
SITE NAME OR SITE NUMBER: J. H. Reese

VESSEL NO.: 1A (Purchased)

VESSEL FORM: Jar with four rim peaks (Figure 3)

NON-PLASTICS AND PASTE: grog and bone

RIM AND LIP FORM: Everted rim and rounded, exterior folded lip

CORE COLOR: $\mathrm{G}$ (fired in a reducing environment and cooled in the open air)

INTERIOR SURFACE COLOR:

dark grayish-brown

EXTERIOR SURFACE COLOR:

reddish-brown; fire clouds on the rim,

body, and base

WALL THICKNESS (IN MM):

rim, $6.5 \mathrm{~mm}$

INTERIOR SURFACE

TREATMENT: smoothed

EXTERIOR SURFACE

TREATMENT: smoothed

HEIGHT (IN CM): 15.0

ORIFICE DIAMETER (IN CM): 13.3

DIAMETER AT BOTTOM OF

RIM OR NECK (IN CM): 13.1

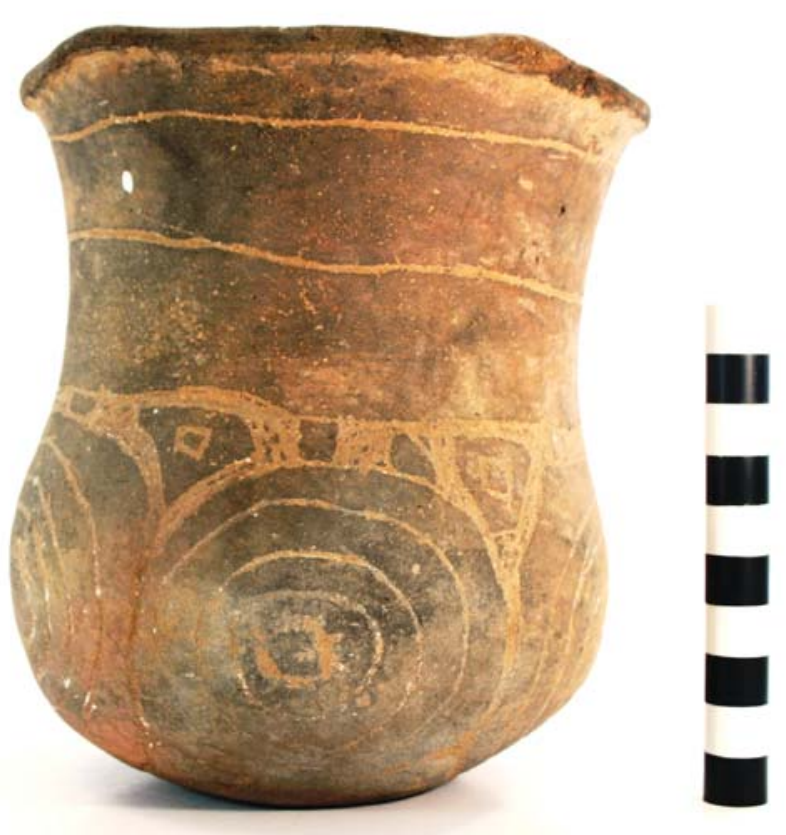

Figure 3. Wilder Engraved, var. unspecified jar from the J. H. Reese site (41WD20.

BASE DIAMETER (IN CM) AND SHAPE OF BASE: 5.2; circular and flat

ESTIMATED VOLUME (IN LITERS): 1.2

DECORATION (INCLUDING MOTIF AND ELEMENTS WHEN APPARENT): The vessel rim has three equally-spaced horizontal engraved lines. The vessel body is divided into four panels by single vertical engraved lines with large upper and lower triangle elements formed by either engraved or wide excised lines. The upper triangle elements have small central diamonds $(n=3)$ or circles $(n=1)$, while the lower triangles have central dots $(n=2)$ or rectangles $(n=2)$. There is a narrow engraved zone between the upper triangle elements that have five sets of vertical excised columns (Figure 3).

In the panels themselves are a series of four centrally-placed concentric engraved circles. The inner concentric circle has a series of linear tick marks on it (see Figure 3).

PIGMENT USE AND LOCATION ON VESSEL: white clay pigment in the engraved lines

TYPE AND VARIETY (IF KNOWN): Wilder Engraved, var. unspecified 
SITE NAME OR SITE NUMBER: J. H. Reese

VESSEL NO.: 3, Burial 1

VESSEL FORM: Carinated bowl

NON-PLASTICS AND PASTE: grog

RIM AND LIP FORM: Direct rim and rounded, exterior folded lip

CORE COLOR: $\mathrm{F}$ (fired in a reducing environment and cooled in the open air)

INTERIOR SURFACE COLOR:

brown; fire clouds on the base

EXTERIOR SURFACE COLOR:

brown; fire clouds on the

rim and body

WALL THICKNESS (IN MM):

rim, $6.5 \mathrm{~mm}$

INTERIOR SURFACE

TREATMENT: smoothed

EXTERIOR SURFACE

TREATMENT: smoothed

HEIGHT (IN CM): 14.4

ORIFICE DIAMETER

(IN CM): 24.0

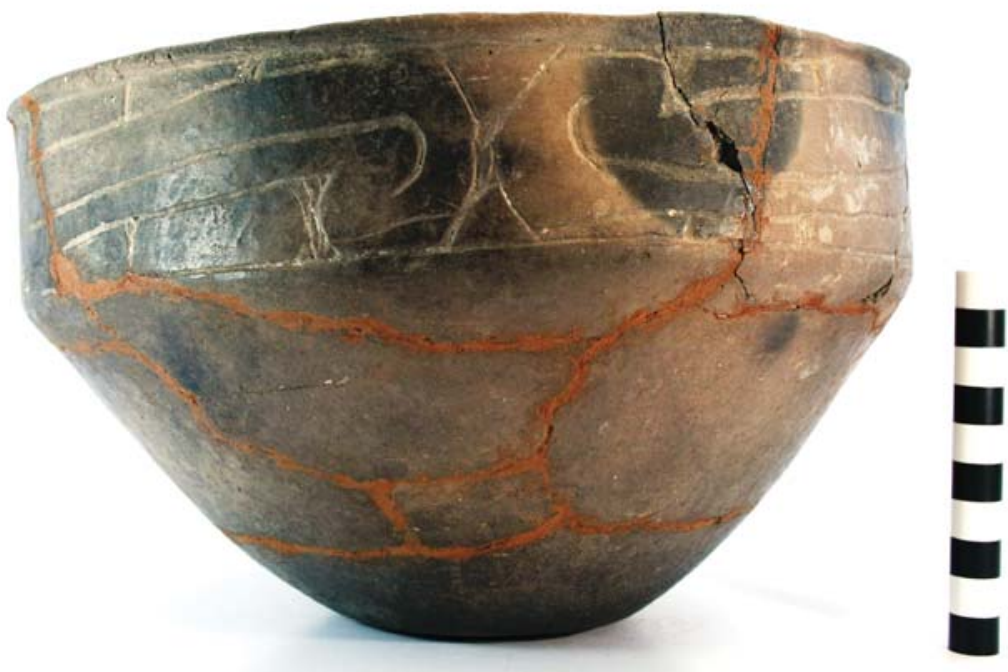

DIAMETER AT BOTTOM

Figure 4. Ripley Engraved, var. Gandy carinated bowl from Burial 1 at the J. H. Reese site (41WD2).

OF RIM OR NECK (IN CM): 24.0

BASE DIAMETER (IN CM) AND SHAPE OF BASE: 8.5; circular and flat

ESTIMATED VOLUME (IN LITERS): 3.1

DECORATION (INCLUDING MOTIF AND ELEMENTS WHEN APPARENT): The rim has an engraved scroll motif repeated four times around the vessel. The scrolls are divided by engraved brackets with a central cross-hatched zone. The engraved scrolls are horizontal and end in a hooked arm element. The upper and lower scroll fill zones have excised brackets, vertical excised columns or lines, and excised triangle elements (Figure 4).

PIGMENT USE AND LOCATION ON VESSEL: white clay pigment in the engraved lines

TYPE AND VARIETY (IF KNOWN): Ripley Engraved, var. Gandy 
SITE NAME OR SITE NUMBER: J. H. Reese

VESSEL NO.: 4, Burial 1

VESSEL FORM: Carinated bowl

NON-PLASTICS AND PASTE: grog

RIM AND LIP FORM: Direct rim and rounded, exterior folded lip

CORE COLOR: $\mathrm{G}$ (fired in a reducing environment and cooled in the open air)

INTERIOR SURFACE COLOR: dark grayish-brown

EXTERIOR SURFACE COLOR: brown; fire clouds on the rim, body, and base

WALL THICKNESS (IN MM): rim, 6.7 mm

INTERIOR SURFACE

TREATMENT: smoothed

EXTERIOR SURFACE

TREATMENT: smoothed

HEIGHT (IN CM): 11.5

ORIFICE DIAMETER

(IN CM): 20.5

DIAMETER AT

BOTTOM OF RIM OR

NECK (IN CM): 19.5

BASE DIAMETER (IN CM) AND SHAPE OF BASE: 6.5 ; circular and flat

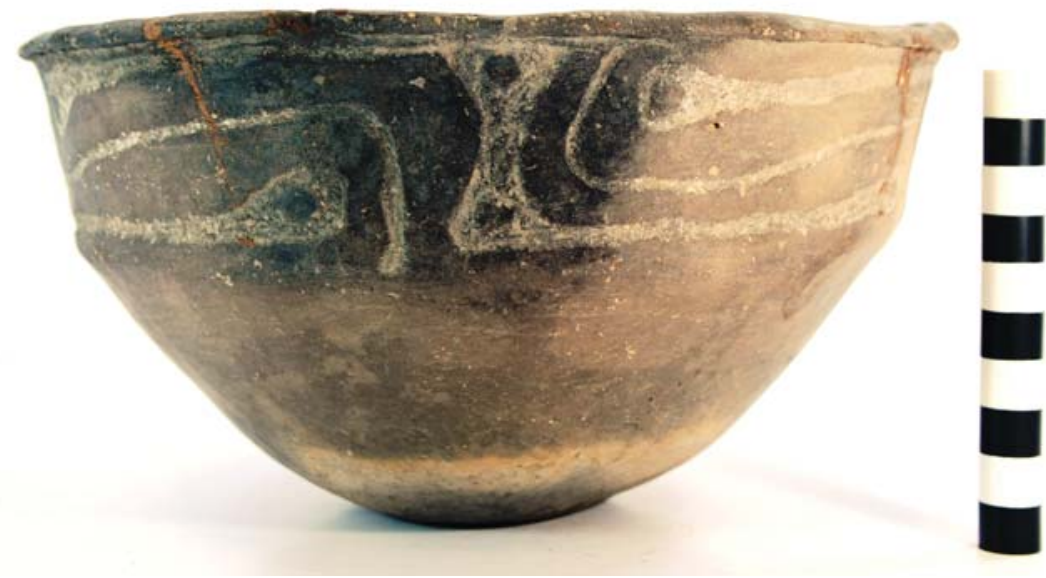

Figure 5. Ripley Engraved, var. Gandy carinated bowl from Burial 1 at the J. H. Reese site (41WD2).

ESTIMATED VOLUME (IN LITERS): 1.4

DECORATION (INCLUDING MOTIF AND ELEMENTS WHEN APPARENT): The rim has an engraved horizontal and vertical scroll motif repeated four times around the vessel. The scroll motifs are divided by excised brackets that have two negative circles. Connected to the brackets are upper and lower narrow excised zones; these have a single negative circle at their outer edge (Figure 5).

PIGMENT USE AND LOCATION ON VESSEL: none

TYPE AND VARIETY (IF KNOWN): Ripley Engraved, var. Gandy 
SITE NAME OR SITE NUMBER: J. H. Reese

VESSEL NO.: 6, Burial 1

VESSEL FORM: Carinated bowl

NON-PLASTICS AND PASTE: grog

RIM AND LIP FORM: Direct rim and rounded, exterior folded lip

CORE COLOR: F (fired in a reducing environment and cooled in the open air)

INTERIOR SURFACE COLOR:

brown; fire clouds on the rim,

body, and base

EXTERIOR SURFACE COLOR:

brown; fire clouds on the body and base

WALL THICKNESS (IN MM):

rim, $6.3 \mathrm{~mm}$

INTERIOR SURFACE

TREATMENT: smoothed

EXTERIOR SURFACE

TREATMENT: smoothed

HEIGHT (IN CM): 6.6

ORIFICE DIAMETER

(IN CM): 11.8

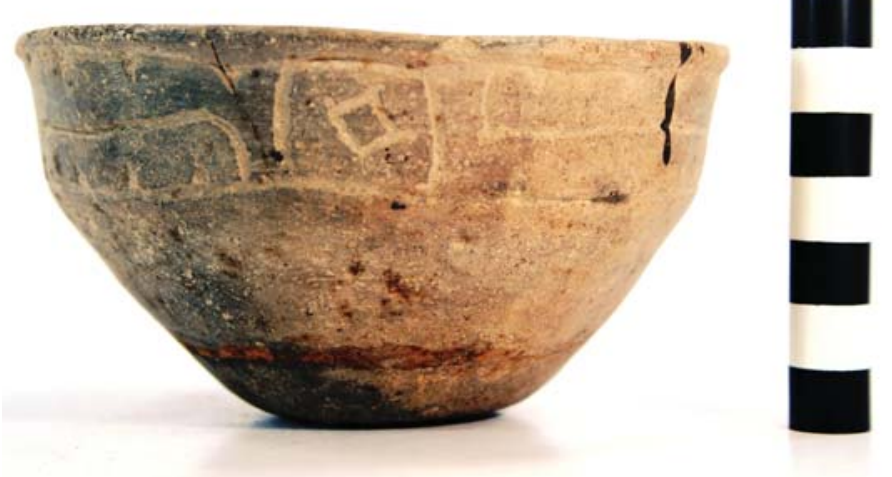

Figure 6. Ripley Engraved, var. McKinney carinated bowl from Burial 1 at the J. H. Reese site (41WD2).

DIAMETER AT BOTTOM OF RIM OR NECK (IN CM): 11.5

BASE DIAMETER (IN CM) AND SHAPE OF BASE: 4.5; circular and flat

ESTIMATED VOLUME (IN LITERS): 0.5

DECORATION (INCLUDING MOTIF AND ELEMENTS WHEN APPARENT): The vessel rim has an engraved horizontal and vertical scroll motif repeated four times around the vessel. The horizontal lines above and below the scrolls have excised pendant triangles either pointing towards the carination or towards the rim. The scrolls are divided from each other by either hatched brackets $(n=2)$ or vertical engraved semicircles with a central diamond element $(n=2)$ (Figure 6).

PIGMENT USE AND LOCATION ON VESSEL: none

TYPE AND VARIETY (IF KNOWN): Ripley Engraved, var. McKinney 
SITE NAME OR SITE NUMBER: J. H. Reese

VESSEL NO.: 7, Burial 1

VESSEL FORM: Carinated bowl

NON-PLASTICS AND PASTE: grog

RIM AND LIP FORM: Inverted rim and rounded lip

CORE COLOR: B (fired and cooled in a reducing environment)

INTERIOR SURFACE COLOR: black

EXTERIOR SURFACE COLOR: black; fire clouds on the body

WALL THICKNESS (IN MM):

rim, $5.3 \mathrm{~mm}$

INTERIOR SURFACE

TREATMENT: smoothed

EXTERIOR SURFACE

TREATMENT: smoothed

HEIGHT (IN CM): 5.0

ORIFICE DIAMETER

(IN CM): 5.5

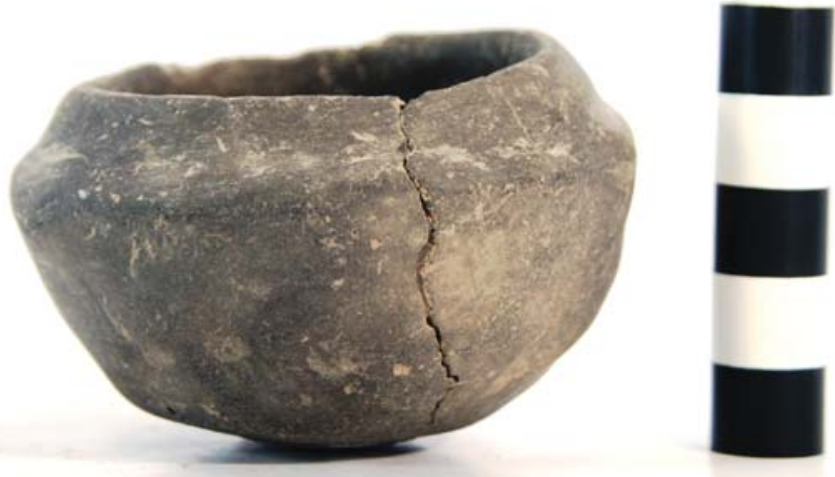

DIAMETER AT BOTTOM

OF RIM OR NECK (IN CM): 7.0

Figure 7. Plain carinated bowl in Burial 1 at the J. H. Reese site (41WD2).

BASE DIAMETER (IN CM) AND SHAPE OF BASE: 4.0; circular and rounded

ESTIMATED VOLUME (IN LITERS): 0.2

DECORATION (INCLUDING MOTIF AND ELEMENTS WHEN APPARENT): Plain (Figure 7)

PIGMENT USE AND LOCATION ON VESSEL: none

TYPE AND VARIETY (IF KNOWN): Unidentified plain ware 
SITE NAME OR SITE NUMBER: J. H. Reese

VESSEL NO.: 8, Burial 1

VESSEL FORM: Carinated bowl

NON-PLASTICS AND PASTE: grog

RIM AND LIP FORM: Direct rim and rounded lip

CORE COLOR: $\mathrm{F}$ (fired in a reducing environment and cooled in the open air)

INTERIOR SURFACE COLOR: red

EXTERIOR SURFACE

COLOR: red

WALL THICKNESS (IN MM):

rim, $6.3 \mathrm{~mm}$

INTERIOR SURFACE

TREATMENT: smoothed

EXTERIOR SURFACE

TREATMENT: burnished

HEIGHT (IN CM): 7.8

ORIFICE DIAMETER

(IN CM): 12.7

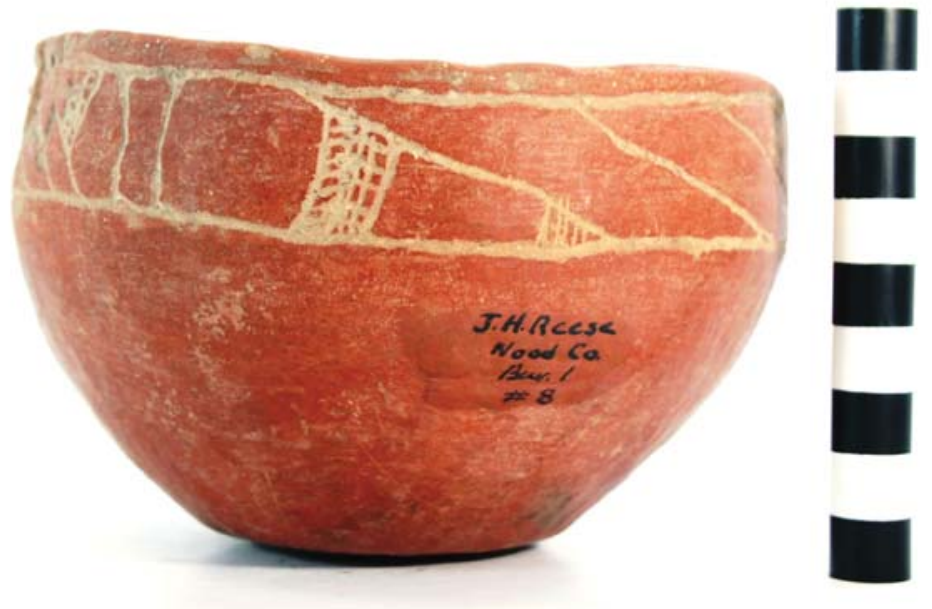

Figure 8. Ripley Engraved, var. unspecified carinated bowl in

DIAMETER AT BOTTOM OF

Burial 1 at the J. H. Reese site (41WD2).

RIM OR NECK (IN CM): 12.7

BASE DIAMETER (IN CM) AND SHAPE OF BASE: 5.8; circular and flat

ESTIMATED VOLUME (IN LITERS): 0.6

DECORATION (INCLUDING MOTIF AND ELEMENTS WHEN APPARENT): The interior and exterior vessel surfaces have a red clay slip. On the exterior rim are a series of multiple or single diagonal engraved lines with rectangular and bracket-shaped cross-hatched zones pendant from the diagonal lines. There are also triangular-shaped zones at the base of several diagonal lines that are filled with hatched lines (Figure 8).

PIGMENT USE AND LOCATION ON VESSEL: none

TYPE AND VARIETY (IF KNOWN): Ripley Engraved, var. unspecified 
SITE NAME OR SITE NUMBER: J. H. Reese

VESSEL NO.: 9, Burial 1

VESSEL FORM: Carinated bowl

NON-PLASTICS AND PASTE: grog

RIM AND LIP FORM: Everted rim and rounded, exterior folded lip

CORE COLOR: B (fired and cooled in a reducing environment)

INTERIOR SURFACE COLOR: black; fire clouds on the rim and body

EXTERIOR SURFACE COLOR: black; fire clouds on the body

WALL THICKNESS (IN MM):

rim, $6.9 \mathrm{~mm}$

INTERIOR SURFACE

TREATMENT: smoothed

EXTERIOR SURFACE

TREATMENT: smoothed

HEIGHT (IN CM): 13.4

ORIFICE DIAMETER

(IN CM): 27.5

DIAMETER AT BOTTOM OF

RIM OR NECK (IN CM): 22.5

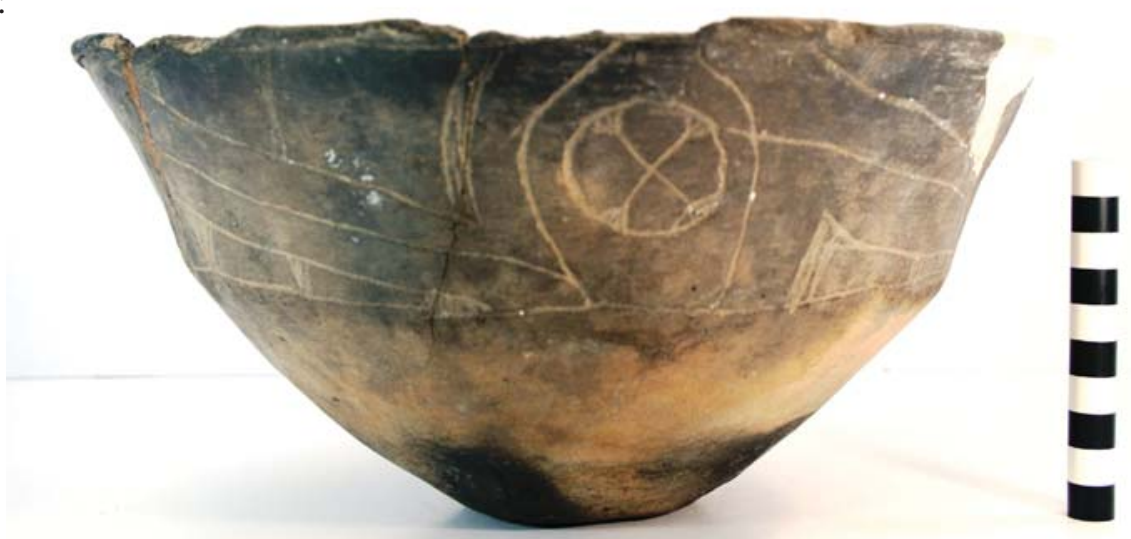

Figure 9. Ripley Engraved, var. Galt carinated bowl in Burial 1 at the J. H. Reese site (41WD2).

BASE DIAMETER (IN CM) AND SHAPE OF BASE: 6.5; circular and flat

ESTIMATED VOLUME (IN LITERS): 3.3

DECORATION (INCLUDING MOTIF AND ELEMENTS WHEN APPARENT): The rim has an engraved slanted scroll and circle motif repeated four times around the vessel. The central circle element has two concentric circles, the innermost and smaller circle with horizontal and vertical equal arm lines with four hatched triangles at the end of each of the lines. The upper and lower scroll fill zones have hatched, crosshatched, or excised columns (Figure 9).

PIGMENT USE AND LOCATION ON VESSEL: none

TYPE AND VARIETY (IF KNOWN): Ripley Engraved, var. Galt 
SITE NAME OR SITE NUMBER: J. H. Reese

VESSEL NO.: 10, Burial 1

VESSEL FORM: Jar

NON-PLASTICS AND PASTE: grog

RIM AND LIP FORM: Everted rim and rounded lip

CORE COLOR: B (fired and cooled in a reducing environment)

INTERIOR SURFACE COLOR: very dark grayish-brown

EXTERIOR SURFACE COLOR: dark grayish-brown; fire clouds on the rim, body, and base; organic residue on the rim and body

WALL THICKNESS (IN MM): rim, $6.4 \mathrm{~mm}$

INTERIOR SURFACE TREATMENT: smoothed

EXTERIOR SURFACE

TREATMENT: smoothed on the body

HEIGHT (IN CM): 14.6

ORIFICE DIAMETER (IN CM): 12.6

DIAMETER AT BOTTOM OF RIM

OR NECK (IN CM): 12.0

BASE DIAMETER (IN CM) AND SHAPE OF BASE: 7.6; circular and flat

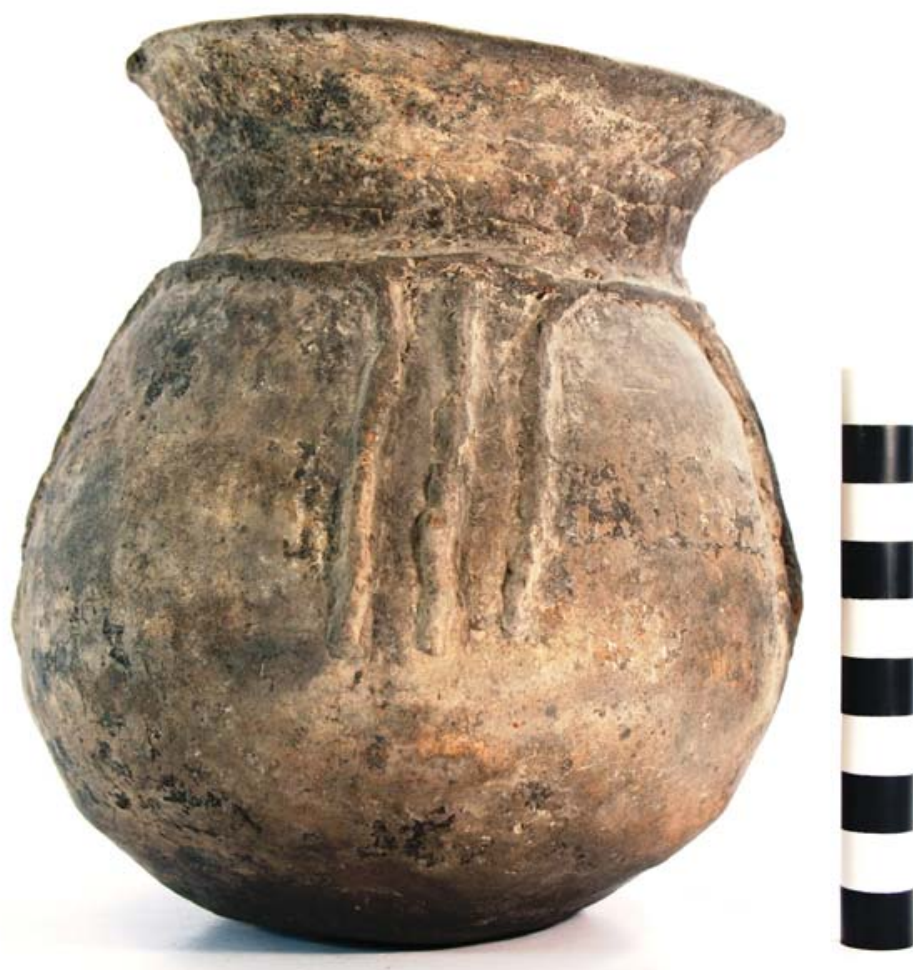

Figure 10. La Rue Neck Banded jar in Burial 1 at the J. H. Reese site (41WD2).

ESTIMATED VOLUME (IN LITERS): 1.1

DECORATION (INCLUDING MOTIF AND ELEMENTS WHEN APPARENT): The rim has five horizontal rows of neck bands. The vessel body has two horizontal appliqued ridges at the upper body, and four series of three vertical appliqued ridges that extend to within $6.4 \mathrm{~cm}$ of the vessel base (Figure 10).

PIGMENT USE AND LOCATION ON VESSEL: none

TYPE AND VARIETY (IF KNOWN): La Rue Neck Banded 
SITE NAME OR SITE NUMBER: J. H. Reese

VESSEL NO.: 11, Burial 1

VESSEL FORM: Jar with four sets of two appliqued lugs (Figure 11)

NON-PLASTICS AND PASTE: grog

RIM AND LIP FORM: Everted rim and rounded, exterior folded lip

CORE COLOR: $\mathrm{F}$ (fired in a reducing environment and cooled in the open air)

INTERIOR SURFACE COLOR: brown; fire clouds on the rim

EXTERIOR SURFACE COLOR: brown; fire clouds on the body

WALL THICKNESS (IN MM): rim, $4.1 \mathrm{~mm}$; body, $5.1 \mathrm{~mm}$

INTERIOR SURFACE TREATMENT: smoothed

EXTERIOR SURFACE TREATMENT: smoothed on the body

HEIGHT (IN CM): 14.8

ORIFICE DIAMETER (IN CM): 12.3

DIAMETER AT BOTTOM OF RIM OR NECK (IN CM): 11.0

BASE DIAMETER (IN CM) AND SHAPE OF BASE: 6.0;

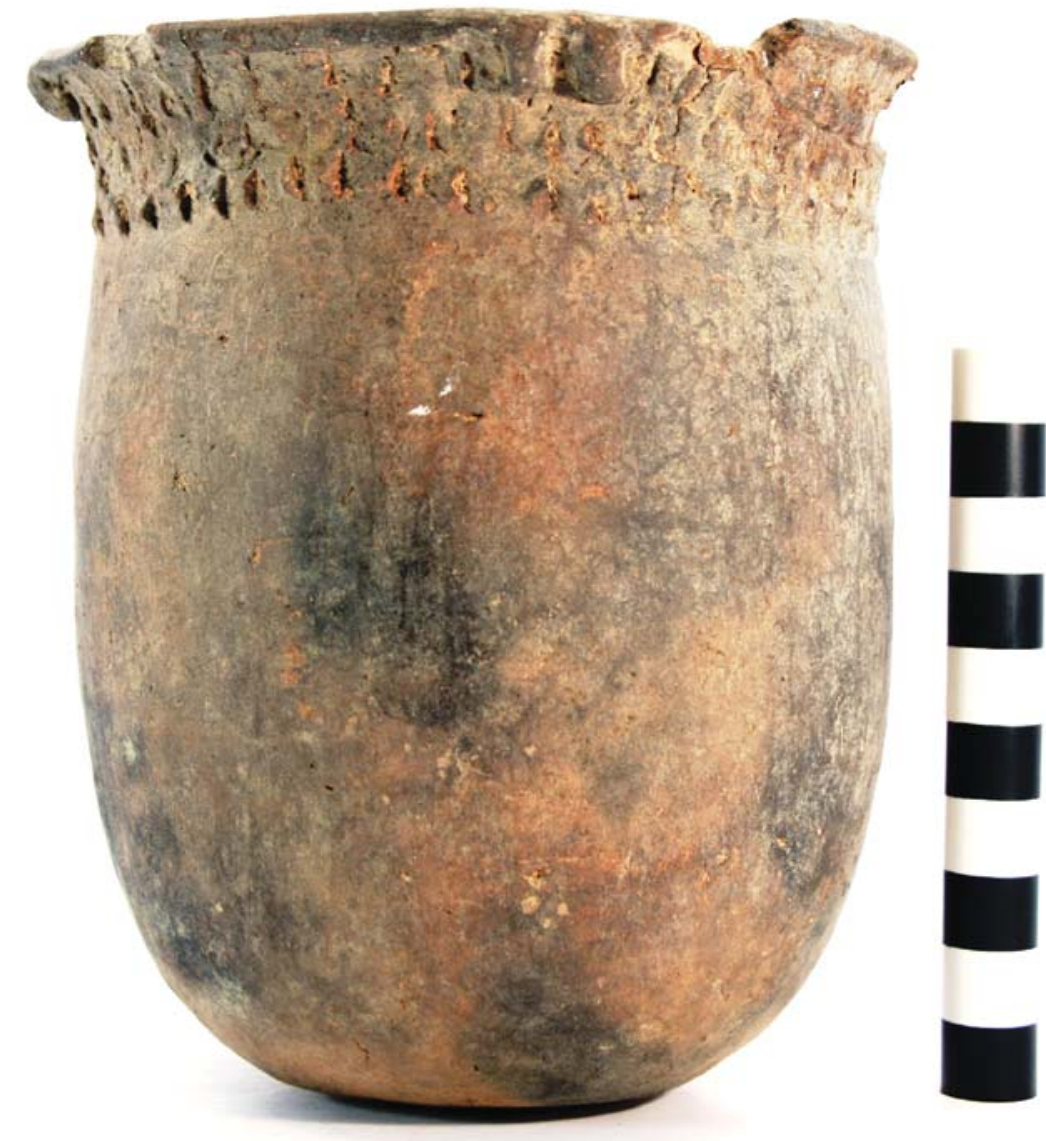

Figure 11. Mockingbird Punctated jar in Burial 1 at the J. H. Reese site (41WD2).

circular and flat

ESTIMATED VOLUME (IN LITERS): 1.1

DECORATION (INCLUDING MOTIF AND ELEMENTS WHEN APPARENT): The vessel rim has four horizontal rows of tool punctations (Figure 11).

PIGMENT USE AND LOCATION ON VESSEL: none

TYPE AND VARIETY (IF KNOWN): Mockingbird Punctated 
SITE NAME OR SITE NUMBER: J. H. Reese

VESSEL NO.: 12, Burial 1

VESSEL FORM: Jar with four rim peaks (Figure 12)

NON-PLASTICS AND PASTE: grog

RIM AND LIP FORM: Everted rim and rounded, exterior folded lip

CORE COLOR: G (fired in a reducing environment and cooled in the open air)

INTERIOR SURFACE COLOR: dark grayish-brown

EXTERIOR SURFACE COLOR: yellowish-brown; fire clouds on the rim, body, and base; thick organic residue on the rim and body (sample of organic residue collected as a radiocarbon sample)

WALL THICKNESS (IN MM): rim, $4.9 \mathrm{~mm}$

INTERIOR SURFACE TREATMENT: smoothed EXTERIOR SURFACE TREATMENT: smoothed on the body

HEIGHT (IN CM): 11.5

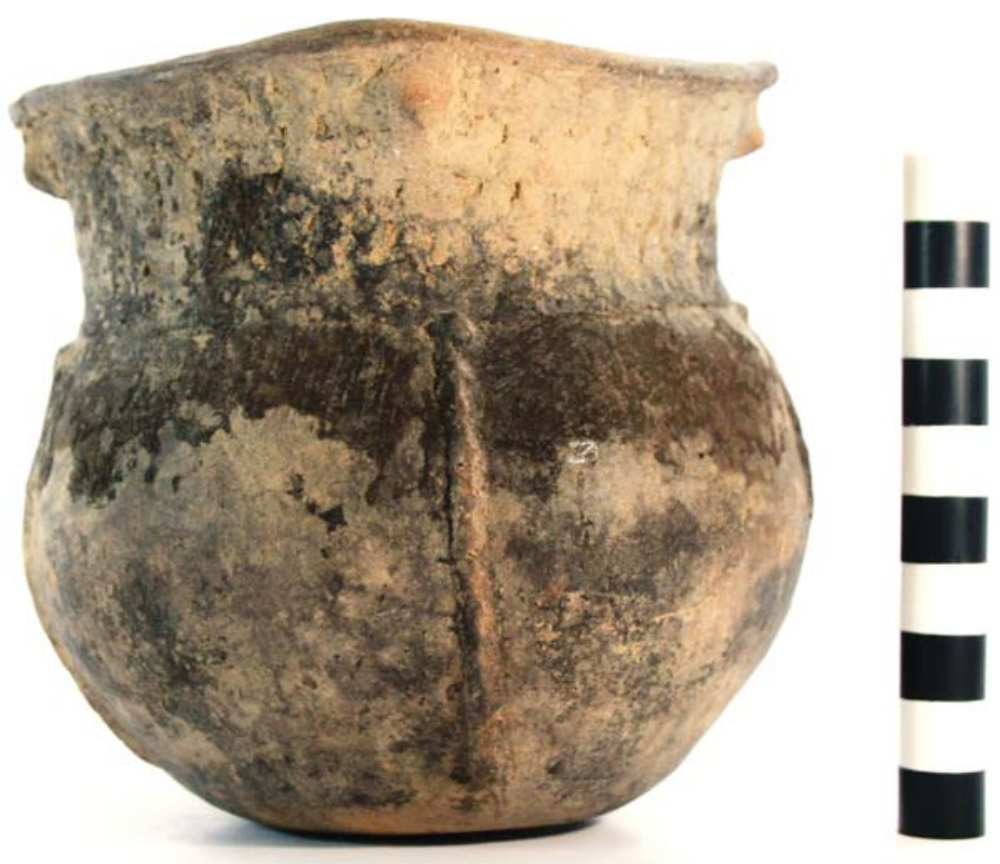

Figure 12. La Rue Neck Banded jar in Burial 1 at the J. H. Reese site (41WD2).

ORIFICE DIAMETER (IN CM): 12.1

DIAMETER AT BOTTOM OF RIM OR NECK (IN CM): 11.7

BASE DIAMETER (IN CM) AND SHAPE OF BASE: 5.3; circular and flat

ESTIMATED VOLUME (IN LITERS): 0.8

DECORATION (INCLUDING MOTIFANDELEMENTS WHENAPPARENT): The rim has four horizontal rows of neck bands, and there are four appliqued nodes on the rim beneath each of the rim peaks. The vessel body has four vertical appliqued ridges; these ridges begin on the body underneath the rim peaks (Figure 12).

PIGMENT USE AND LOCATION ON VESSEL: none

TYPE AND VARIETY (IF KNOWN): La Rue Neck Banded 
SITE NAME OR SITE NUMBER: J. H. Reese

VESSEL NO.: 13, Burial 1

VESSEL FORM: Jar

NON-PLASTICS AND PASTE: grog

RIM AND LIP FORM: Everted rim and rounded lip

CORE COLOR: $\mathrm{G}$ (fired in a reducing environment and cooled in the open air)

INTERIOR SURFACE COLOR:

dark grayish-brown

EXTERIOR SURFACE COLOR:

brown; fire clouds on the rim, body, and base; organic residue on the rim and upper body

WALL THICKNESS (IN MM):

rim, $6.4 \mathrm{~mm}$

INTERIOR SURFACE

TREATMENT: smoothed

EXTERIOR SURFACE

TREATMENT: none

HEIGHT (IN CM): 18.4

ORIFICE DIAMETER

(IN CM): 18.5

DIAMETER AT BOTTOM OF

RIM OR NECK (IN CM): 17.7

BASE DIAMETER (IN CM) AND

SHAPE OF BASE: 7.0; circular and flat

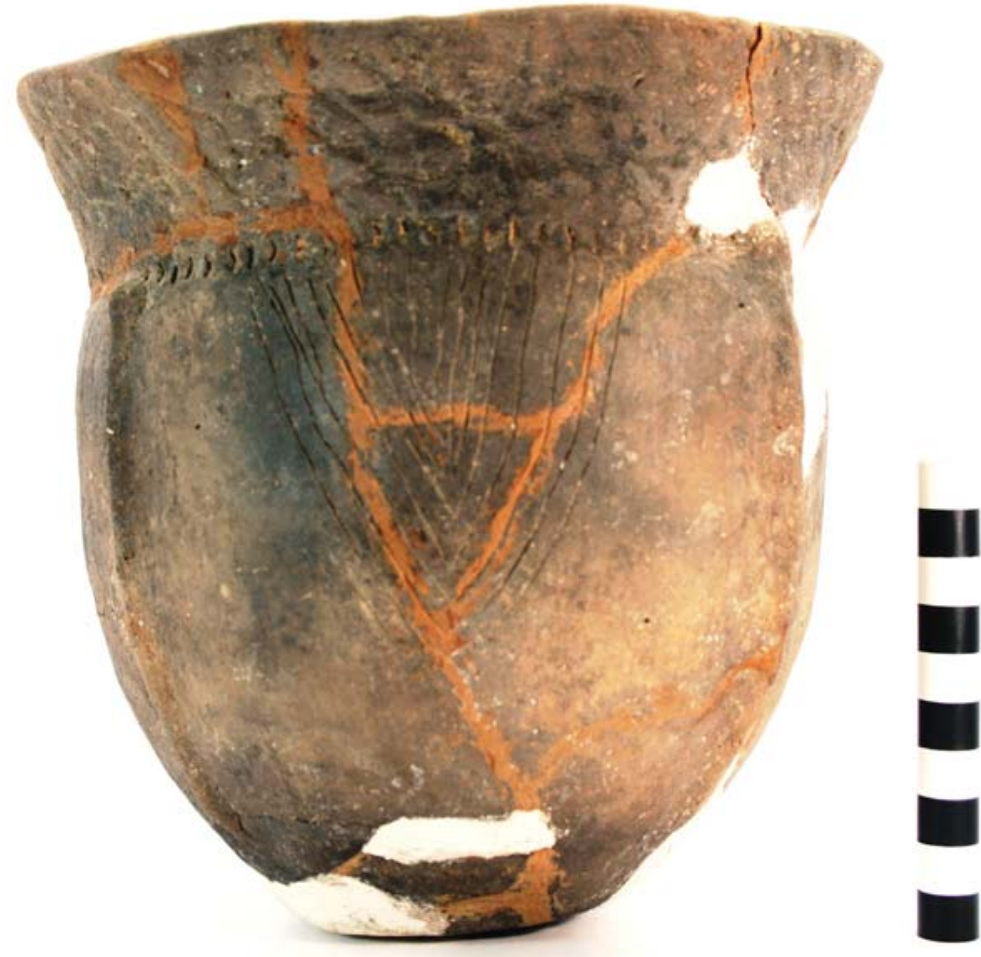

Figure 13. La Rue Neck Banded jar in Burial 1 at the J. H. Reese site (41WD2).

ESTIMATED VOLUME (IN LITERS): 3.1

DECORATION (INCLUDING MOTIF AND ELEMENTS WHEN APPARENT): The vessel rim has four horizontal rows of neck bands as well as a single row of tool punctations at the rim-body juncture. The vessel body is divided into four panels by vertical appliqued ridges that extend to within $2.5 \mathrm{~cm}$ of the vessel body. The panels themselves have a series of increasingly larger and nested incised triangles; the innermost incised triangle element has vertical hatched incised lines (Figure 13).

PIGMENT USE AND LOCATION ON VESSEL: none

TYPE AND VARIETY (IF KNOWN): La Rue Neck Banded 
SITE NAME OR SITE NUMBER: J. H. Reese

VESSEL NO.: 14, Burial 1

VESSEL FORM: Bottle

NON-PLASTICS AND PASTE: grog

RIM AND LIP FORM: Everted rim and rounded lip

CORE COLOR: $\mathrm{F}$ (fired in a

reducing environment and cooled

in the open air)

INTERIOR SURFACE COLOR:

brown

EXTERIOR SURFACE COLOR:

reddish-brown; fire clouds on the

neck and body

WALL THICKNESS (IN MM):

rim, $4.7 \mathrm{~mm}$

INTERIOR SURFACE

TREATMENT: none

EXTERIOR SURFACE

TREATMENT: smoothed

HEIGHT (IN CM): 9.8

ORIFICE DIAMETER (IN CM): 4.2

DIAMETER AT BOTTOM OF RIM

OR NECK (IN CM): 3.6; maximum

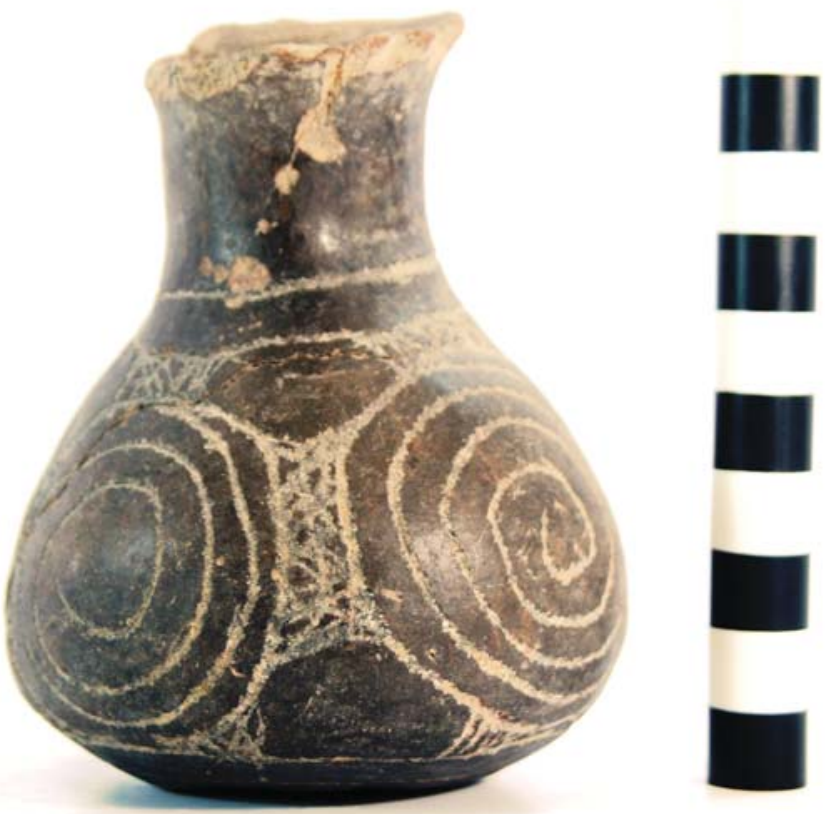

Figure 14. Taylor Engraved bottle in Burial 1 at the J. H. Reese site (41WD2).

body diameter is $8.1 \mathrm{~cm}$.

BASE DIAMETER (IN CM) AND SHAPE OF BASE: 5.2; circular and flat

ESTIMATED VOLUME (IN LITERS): 0.2

DECORATION (INCLUDING MOTIF AND ELEMENTS WHEN APPARENT): The upper and lower parts of the vessel body have two horizontal engraved lines. The remainder of the vessel body has four engraved concentric circle motifs that end in hooked arms. Above and below each of the concentric circle motifs, and pendant from horizontal engraved lines, are triangular engraved zones filled with hatched or cross-hatched lines. The concentric circle motifs are divided by engraved brackets with hatched or cross-hatched corners, and there is a horizontal cross-hatched bracket in the central part of the bracket dividers (Figure 14).

PIGMENT USE AND LOCATION ON VESSEL: white clay pigment in the engraved lines

TYPE AND VARIETY (IF KNOWN): Taylor Engraved 
SITE NAME OR SITE NUMBER: J. H. Reese

VESSEL NO.: 16, Burial 2

VESSEL FORM: Carinated bowl

NON-PLASTICS AND PASTE: grog

RIM AND LIP FORM: Direct rim and rounded, exterior folded lip

CORE COLOR: $\mathrm{G}$ (fired in a reducing environment and cooled in the open air)

INTERIOR SURFACE COLOR: grayish-brown

EXTERIOR SURFACE

COLOR: yellowish-brown; fire clouds on the rim, body, and base

WALL THICKNESS

(IN MM): rim, $6.8 \mathrm{~mm}$

INTERIOR SURFACE

TREATMENT: smoothed

EXTERIOR SURFACE

TREATMENT: smoothed

HEIGHT (IN CM): 15.2

ORIFICE DIAMETER

(IN CM): 29.0

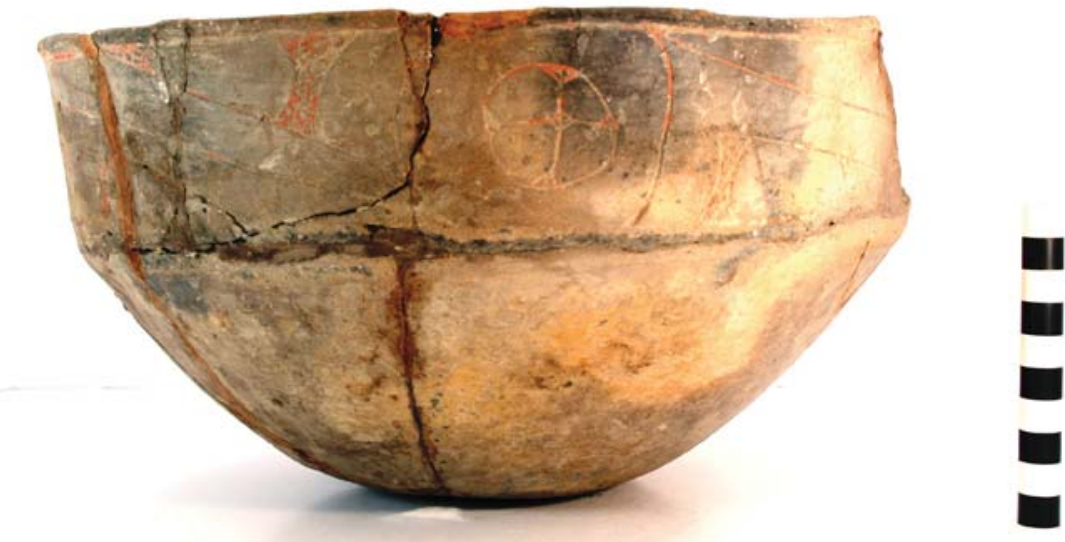

Figure 15. Ripley Engraved, var. Galt carinated bowl in Burial 2 at the J. H. Reese site (41WD2).

DIAMETER AT BOTTOM OF RIM OR NECK (IN CM): 29.0

BASE DIAMETER (IN CM) AND SHAPE OF BASE: 7.6; circular and flat

ESTIMATED VOLUME (IN LITERS): 4.0

DECORATION (INCLUDING MOTIF AND ELEMENTS WHEN APPARENT): The rim panel has four engraved slanted scroll and circle motifs repeated around the vessel. The central circle is within a large semicircle and has horizontal and vertical equal arm lines with open or hatched triangles at the upper end of each of the lines. The upper and lower scroll fill zones have negative oval elements outlined by cross-hatched brackets and cross-hatched triangle elements (Figure 15).

PIGMENT USE AND LOCATION ON VESSEL: red clay pigment in the engraved lines

TYPE AND VARIETY (IF KNOWN): Ripley Engraved, var. Galt 
SITE NAME OR SITE NUMBER: J. H. Reese

VESSEL NO.: 17, Burial 2

VESSEL FORM: Carinated bowl

NON-PLASTICS AND PASTE: grog

RIM AND LIP FORM: Direct rim and rounded, exterior folded lip

CORE COLOR: $\mathrm{G}$ (fired in a reducing environment and cooled in the open air)

INTERIOR SURFACE COLOR: dark grayish-brown

EXTERIOR SURFACE COLOR: yellowish-brown; fire clouds on the rim, body, and base

WALL THICKNESS (IN MM):

rim, $7.8 \mathrm{~mm}$; body, $8.2 \mathrm{~mm}$

INTERIOR SURFACE

TREATMENT: smoothed

EXTERIOR SURFACE

TREATMENT: burnished

HEIGHT (IN CM): 16.5

ORIFICE DIAMETER

(IN CM): 25.0

DIAMETER AT BOTTOM

OF RIM OR NECK (IN CM): 25.0

BASE DIAMETER (IN CM) AND

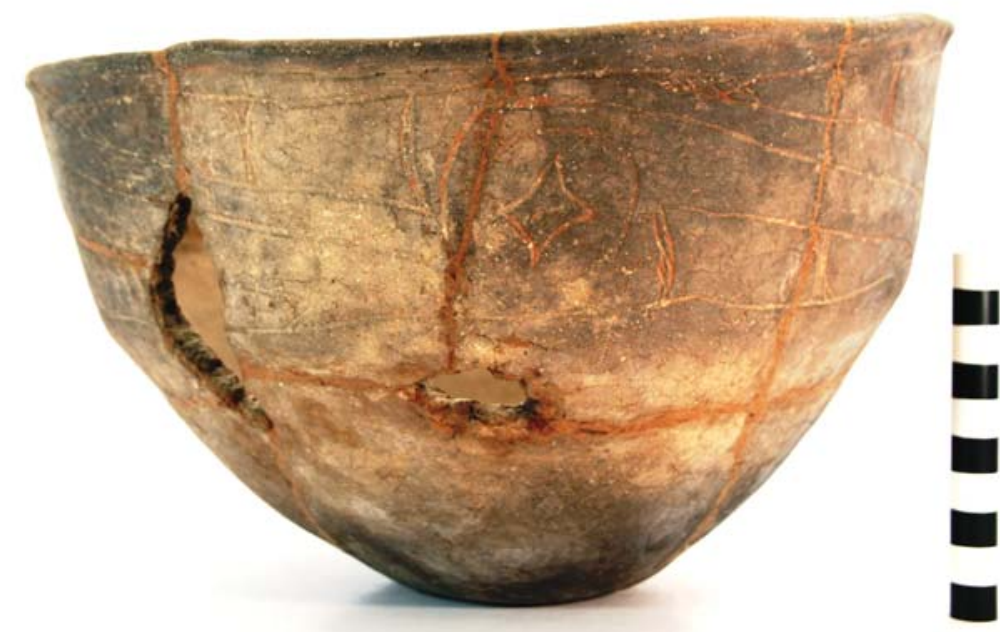

Figure 16. Ripley Engraved, var. Galt carinated bowl in Burial 2 at the J. H. Reese site (41WD2).

SHAPE OF BASE: 7.6; circular and flat

ESTIMATED VOLUME (IN LITERS): 3.7

DECORATION (INCLUDING MOTIF AND ELEMENTS WHEN APPARENT): The rim panel has an engraved slanted scroll and circle motif repeated four times around the vessel. The central circle has an inner diamond element with a central excised dot. The upper scroll fill zones have open and hatched brackets as well as cross-hatched triangles (Figure 16).

PIGMENT USE AND LOCATION ON VESSEL: red clay pigment in the engraved lines

TYPE AND VARIETY (IF KNOWN): Ripley Engraved, var. Galt 
SITE NAME OR SITE NUMBER: J. H. Reese

VESSEL NO.: 18, Burial 2

VESSEL FORM: Carinated bowl

NON-PLASTICS AND PASTE: grog

RIM AND LIP FORM: Direct rim and rounded lip

CORE COLOR: $\mathrm{G}$ (fired in a reducing environment and cooled in the open air)

INTERIOR SURFACE COLOR: grayish-brown

EXTERIOR SURFACE COLOR: yellowish-brown; fire clouds on the rim, body, and base; organic residue on the rim

WALL THICKNESS (IN MM):

rim, $5.5 \mathrm{~mm}$

INTERIOR SURFACE

TREATMENT: none

EXTERIOR SURFACE

TREATMENT: smoothed

HEIGHT (IN CM): 7.6

ORIFICE DIAMETER

(IN CM): 17.1

DIAMETER AT BOTTOM

OF RIM OR NECK (IN CM): 16.9

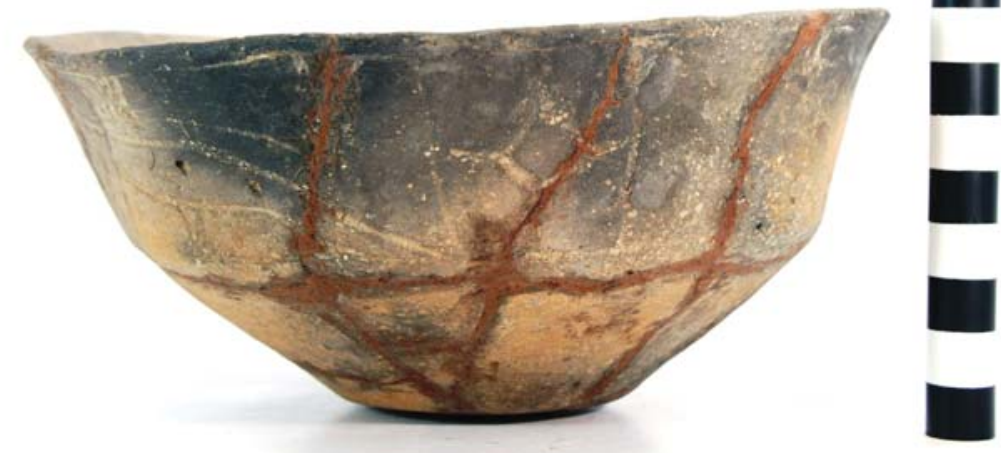

Figure 17. Ripley Engraved, var. Galt carinated bowl in Burial 2 at the J. H. Reese site (41WD2).

BASE DIAMETER (IN CM) AND SHAPE OF BASE: 5.7; circular and flat

ESTIMATED VOLUME (IN LITERS): 0.8

DECORATION (INCLUDING MOTIF AND ELEMENTS WHEN APPARENT): The rim panel has an engraved slanting scroll and central diamond element repeated four times around the vessel. The central diamond element has four excised spur lines, and the two horizontal spur lines are attached to two vertical engraved lines that reach to the vessel carination. The upper and lower scroll fill zones have excised brackets that outline two negative oval elements (Figure 17).

PIGMENT USE AND LOCATION ON VESSEL: none

TYPE AND VARIETY (IF KNOWN): Ripley Engraved, var. Galt 
SITE NAME OR SITE NUMBER: J. H. Reese

VESSEL NO.: 19, Burial 2

VESSEL FORM: Carinated bowl

NON-PLASTICS AND PASTE: grog

RIM AND LIP FORM: Inverted rim and rounded lip

CORE COLOR: B (fired and cooled in a reducing environment)

INTERIOR SURFACE COLOR: dark grayish-brown

EXTERIOR SURFACE

COLOR: dark grayish-brown

WALL THICKNESS (IN MM):

rim, $5.3 \mathrm{~mm}$

INTERIOR SURFACE

TREATMENT: burnished

EXTERIOR SURFACE

TREATMENT: burnished

HEIGHT (IN CM): 7.0

ORIFICE DIAMETER

(IN CM): 11.5

DIAMETER AT BOTTOM OF

RIM OR NECK (IN CM): 11.9

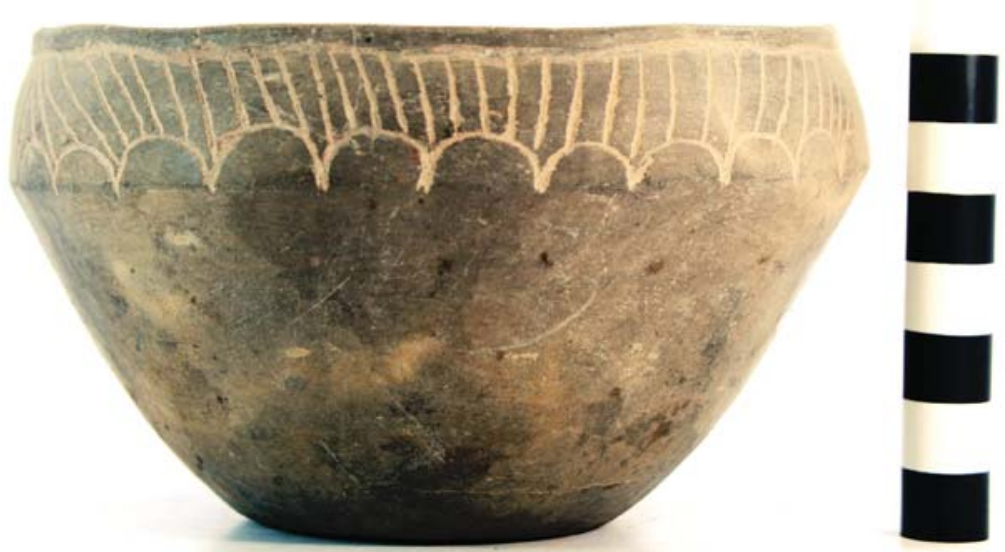

Figure 18. Engraved carinated bowl in Burial 2 at the J. H. Reese site (41WD2).

BASE DIAMETER (IN CM) AND SHAPE OF BASE: 5.1; circular and flat

ESTIMATED VOLUME (IN LITERS): 0.5

DECORATION (INCLUDING MOTIF AND ELEMENTS WHEN APPARENT): The rim is decorated with a single horizontal engraved line beneath the vessel lip as well as a continuous series of diagonal engraved lines within a zone marked by rounded and curvilinear lines at the base of the engraved zone (Figure 18).

PIGMENT USE AND LOCATION ON VESSEL: none

TYPE AND VARIETY (IF KNOWN): Unidentified fine ware 
SITE NAME OR SITE NUMBER: J. H. Reese

VESSEL NO.: 20, Burial 2

VESSEL FORM: Jar

NON-PLASTICS AND PASTE: grog

RIM AND LIP FORM: Everted rim and rounded lip

CORE COLOR: F (fired in a reducing environment and cooled in the open air)

INTERIOR SURFACE COLOR: yellowish-brown; fire clouds on the rim

\section{EXTERIOR SURFACE}

COLOR: yellowish-brown; fire clouds on the rim, body, and base

WALL THICKNESS (IN MM): rim, $6.3 \mathrm{~mm}$; body, $9.6 \mathrm{~mm}$

INTERIOR SURFACE TREATMENT: none

EXTERIOR SURFACE TREATMENT: none

HEIGHT (IN CM): 15.8

ORIFICE DIAMETER

(IN CM): 14.6

DIAMETER AT BOTTOM OF RIM OR NECK (IN CM): 14.0

BASE DIAMETER (IN CM) AND SHAPE OF BASE: 7.0; circular and flat

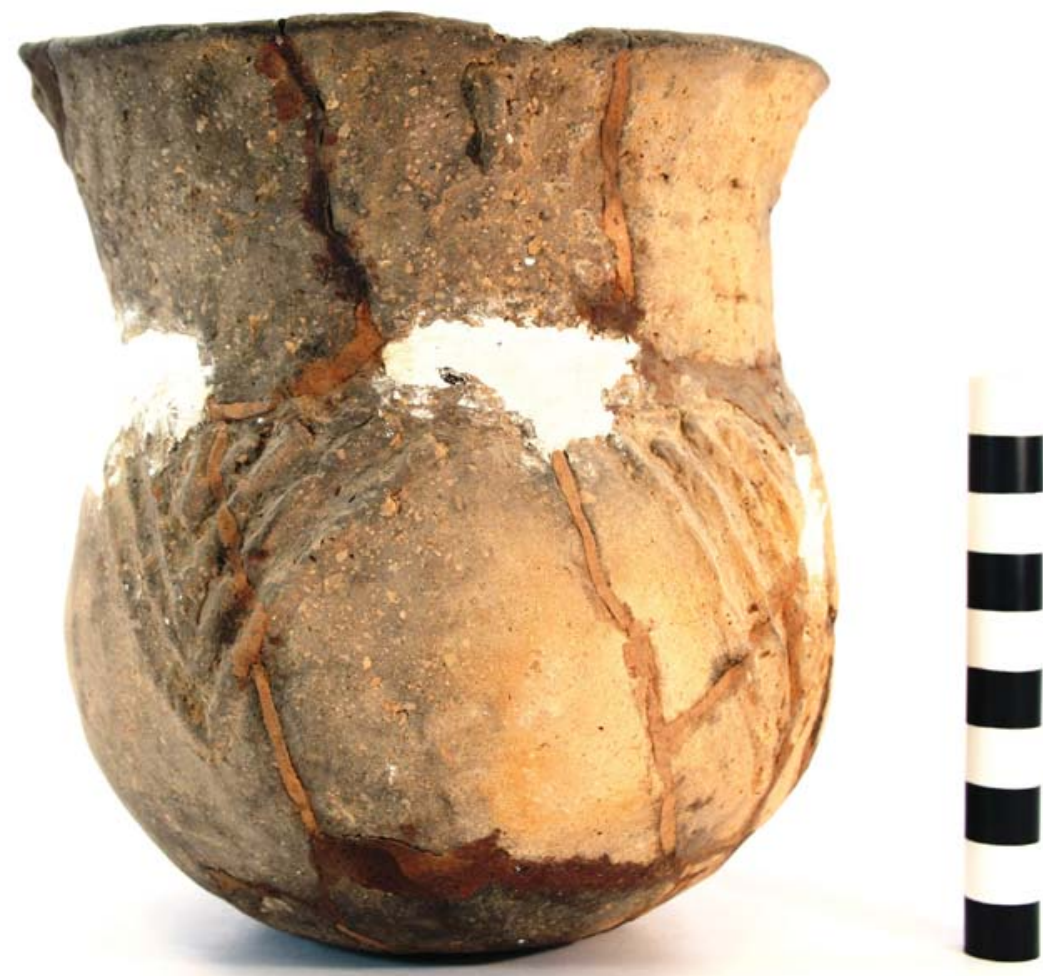

Figure 19. La Rue Neck Banded jar in Burial 2 at the J. H. Reese site (41WD2).

ESTIMATED VOLUME (IN LITERS): 1.4

DECORATION (INCLUDING MOTIFANDELEMENTS WHEN APPARENT): The rim has four horizontal rows of neck bands as well as four appliqued lugs beneath the lip. The vessel body has four sets of appliqued ridge triangle elements beneath the rim-body juncture that are formed by four appliqued ridge triangle elements (Figure 19).

PIGMENT USE AND LOCATION ON VESSEL: none

TYPE AND VARIETY (IF KNOWN): La Rue Neck Banded 
SITE NAME OR SITE NUMBER: J. H. Reese

VESSEL NO.: 21, Burial 2

VESSEL FORM: Jar

NON-PLASTICS AND PASTE: grog

RIM AND LIP FORM: Everted rim and rounded lip

CORE COLOR: B (fired and cooled in a reducing environment)

INTERIOR SURFACE COLOR:

dark grayish-brown

EXTERIOR SURFACE COLOR: dark grayish-brown; fire clouds on the rim and body

WALL THICKNESS (IN MM):

rim, $7.3 \mathrm{~mm}$; body, $8.2 \mathrm{~mm}$

INTERIOR SURFACE

TREATMENT: smoothed

EXTERIOR SURFACE

TREATMENT: smoothed on the body

HEIGHT (IN CM): 30.0

ORIFICE DIAMETER

(IN CM): 22.5

DIAMETER AT BOTTOM OF

RIM OR NECK (IN CM): 22.0

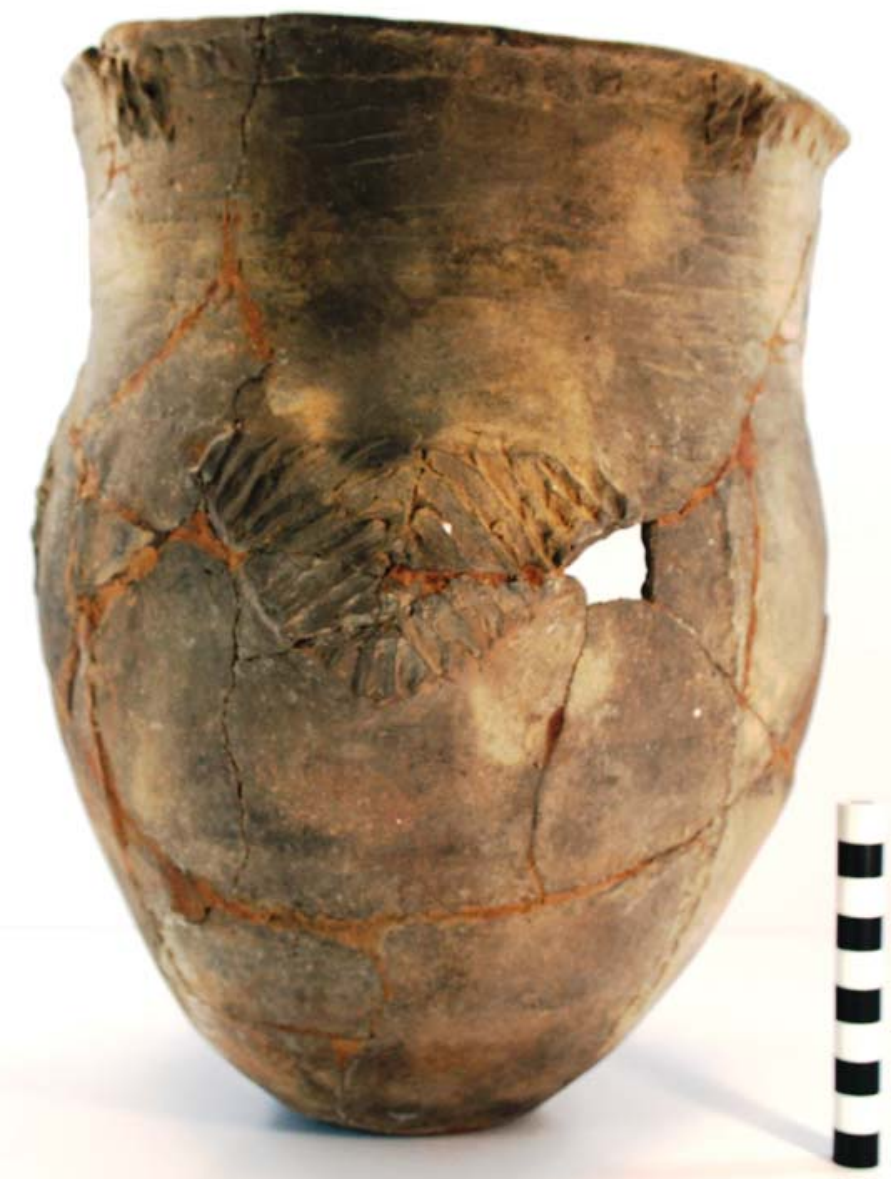

Figure 20. La Rue Neck Banded jar in Burial 2 at the J. H. Reese site (41WD2).

BASE DIAMETER (IN CM) AND SHAPE OF BASE: 7.6; circular and flat

ESTIMATED VOLUME (IN LITERS): 9.0

DECORATION (INCLUDING MOTIFAND ELEMENTS WHEN APPARENT): The rim has one horizontal neck banded row and four or more smoothed over neck banded rows. The vessel body has four appliqued triangle elements filled with diagonally opposed appliqued ridges (Figure 20).

PIGMENT USE AND LOCATION ON VESSEL: none

TYPE AND VARIETY (IF KNOWN): La Rue Neck Banded 
SITE NAME OR SITE NUMBER: J. H. Reese

VESSEL NO.: 22, Burial 2

VESSEL FORM: Carinated bowl

NON-PLASTICS AND PASTE: grog

RIM AND LIP FORM: Direct rim and rounded, exterior folded, lip

CORE COLOR: F (fired in a reducing environment and cooled in the open air)

INTERIOR SURFACE COLOR: brown; fire clouds on the rim, body, and base

EXTERIOR SURFACE COLOR: yellowish-brown; fire clouds on the rim

WALL THICKNESS (IN MM): rim, $7.5 \mathrm{~mm}$

INTERIOR SURFACE

TREATMENT: smoothed

EXTERIOR SURFACE

TREATMENT: smoothed

HEIGHT (IN CM): 14.5

ORIFICE DIAMETER

(IN CM): 27.0

DIAMETER AT BOTTOM

OF RIM OR NECK

(IN CM): 25.0

BASE DIAMETER

(IN CM) AND SHAPE OF

BASE: 8.5 ; circular and flat

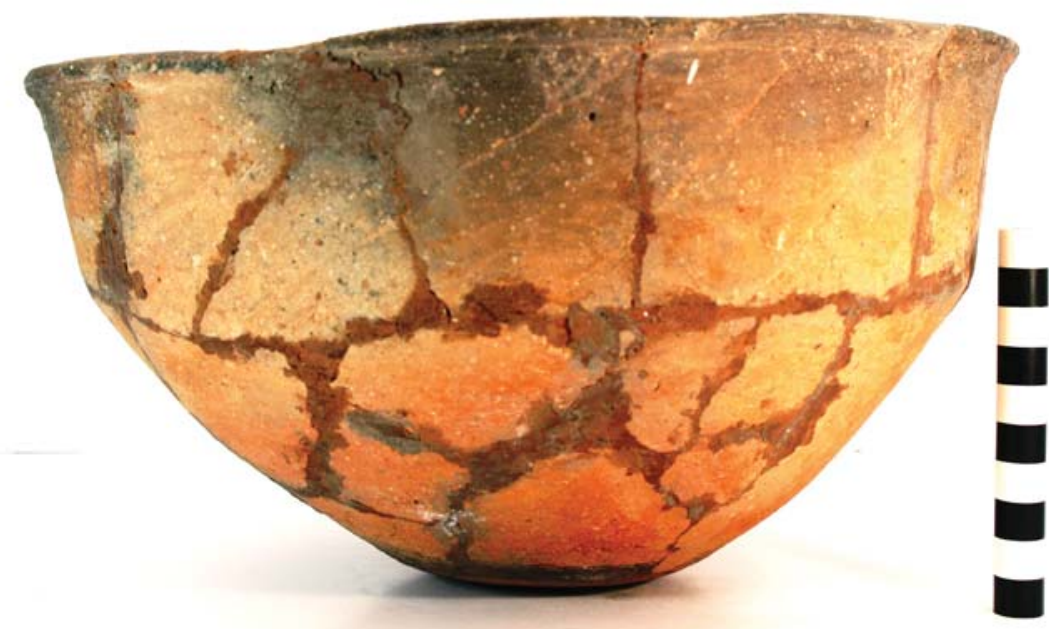

Figure 21. Engraved carinated bowl in Burial 2 at the J. H. Reese site (41WD2).

ESTIMATED VOLUME (IN LITERS): 3.5

DECORATION (INCLUDING MOTIFAND ELEMENTS WHEN APPARENT): The rim panel is decorated with 13 diagonal engraved lines. Alternating lines have upper and lower engraved pendant triangles filled with cross-hatched engraved lines (Figure 21).

PIGMENT USE AND LOCATION ON VESSEL: none

TYPE AND VARIETY (IF KNOWN): Unidentified fine ware 
SITE NAME OR SITE NUMBER: J. H. Reese

VESSEL NO.: 23, Burial 2

VESSEL FORM: Bottle

NON-PLASTICS AND PASTE: grog

RIM AND LIP FORM: Everted rim and rounded lip

CORE COLOR: $\mathrm{G}$ (fired in a reducing

environment and cooled in the open air)

INTERIOR SURFACE COLOR:

dark grayish-brown

EXTERIOR SURFACE COLOR:

yellowish-brown; fire clouds on the

rim, body, and base

WALL THICKNESS (IN MM):

rim, $5.7 \mathrm{~mm}$

INTERIOR SURFACE

TREATMENT: none

EXTERIOR SURFACE

TREATMENT: burnished

HEIGHT (IN CM): 20.3

ORIFICE DIAMETER (IN CM): 5.1

DIAMETER AT BOTTOM OF RIM

OR NECK (IN CM): 6.1; maximum body diameter is $14.7 \mathrm{~cm}$.

BASE DIAMETER (IN CM) AND

SHAPE OF BASE: 7.6; circular and flat

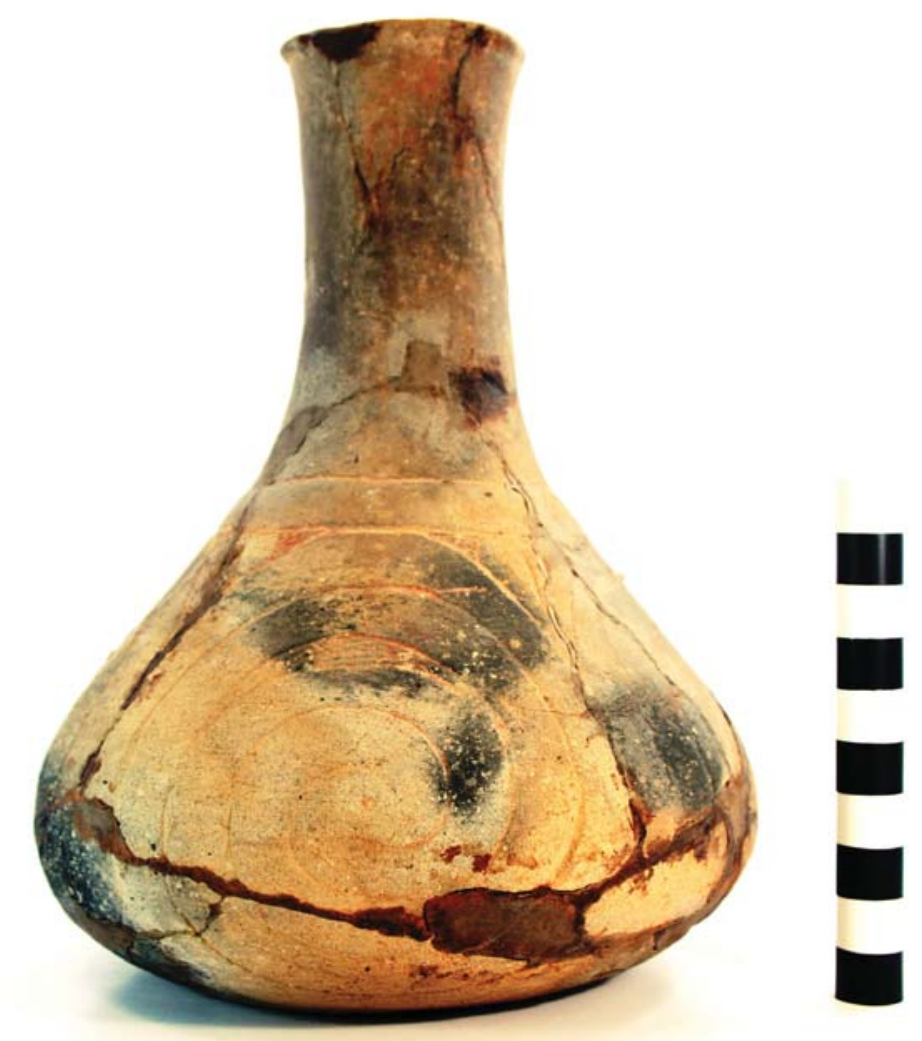

Figure 22. Wilder Engraved, var. unspecified bottle in Burial 2 at the J. H. Reese site (41WD2).

ESTIMATED VOLUME (IN LITERS): 0.6

DECORATION (INCLUDING MOTIF AND ELEMENTS WHEN APPARENT): The upper and lower parts of the vessel body have either two or one horizontal engraved line. Between these engraved lines are four panels defined by a single vertical engraved line with large upper and lower pendant triangles with excised corners. The panels have four sets of concentric circular lines that wrap around each and end in hooked arms that do not meet. Opposite the hooked arms on the concentric circular lines are wider excised zones (Figure 22).

PIGMENT USE AND LOCATION ON VESSEL: red clay pigment in the engraved lines

TYPE AND VARIETY (IF KNOWN): Wilder Engraved, var. unspecified 
SITE NAME OR SITE NUMBER: J. H. Reese

VESSEL NO.: 24, Burial 3

VESSEL FORM: Carinated bowl

NON-PLASTICS AND PASTE: grog

RIM AND LIP FORM: Direct rim and rounded, exterior folded lip

CORE COLOR: $\mathrm{G}$ (fired in a reducing environment and cooled in the open air)

INTERIOR SURFACE COLOR: grayish-brown; fire clouds on the body and base

EXTERIOR SURFACE COLOR: brown; fire clouds on the base

WALL THICKNESS

(IN MM): rim, $6.2 \mathrm{~mm}$

INTERIOR SURFACE

TREATMENT: smoothed

EXTERIOR SURFACE

TREATMENT: smoothed

HEIGHT (IN CM): 7.8

ORIFICE DIAMETER

(IN CM): 15.5

DIAMETER AT BOTTOM

OF RIM OR NECK

(IN CM): 15.0
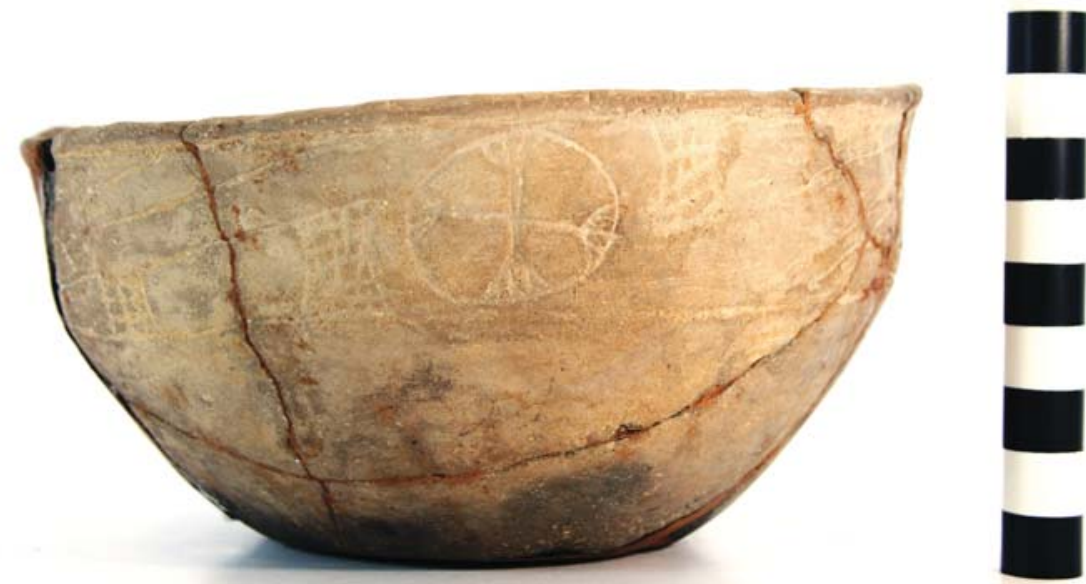

Figure 23. Ripley Engraved, var. Galt carinated bowl in Burial 3 at the J. H. Reese site (41WD2).

BASE DIAMETER (IN CM) AND SHAPE OF BASE: 7.0; circular and flat

ESTIMATED VOLUME (IN LITERS): 0.7

DECORATION (INCLUDING MOTIF AND ELEMENTS WHEN APPARENT): The rim is decorated with an engraved slanted scroll and circle motif repeated three times around the vessel. The central circle in each motif has horizontal and vertical equal arm lines that end in four hatched triangle elements. The upper and lower scroll fill zones have brackets and vertical columns filled with cross-hatched lines; these outline negative ovals and rectangles (Figure 23).

PIGMENT USE AND LOCATION ON VESSEL: none

TYPE AND VARIETY (IF KNOWN): Ripley Engraved, var. Galt 
SITE NAME OR SITE NUMBER: J. H. Reese

VESSEL NO.: 25, Burial 3

VESSEL FORM: Carinated bowl

NON-PLASTICS AND PASTE: grog

RIM AND LIP FORM: Direct rim and rounded, exterior folded, lip

CORE COLOR: $\mathrm{F}$ (fired in a reducing environment and cooled in the open air)

INTERIOR SURFACE COLOR: red

EXTERIOR SURFACE

COLOR: red

WALL THICKNESS

(IN MM): rim, $7.1 \mathrm{~mm}$

INTERIOR SURFACE

TREATMENT: burnished

EXTERIOR SURFACE

TREATMENT: burnished

HEIGHT (IN CM): 8.9

ORIFICE DIAMETER

(IN CM): 17.7

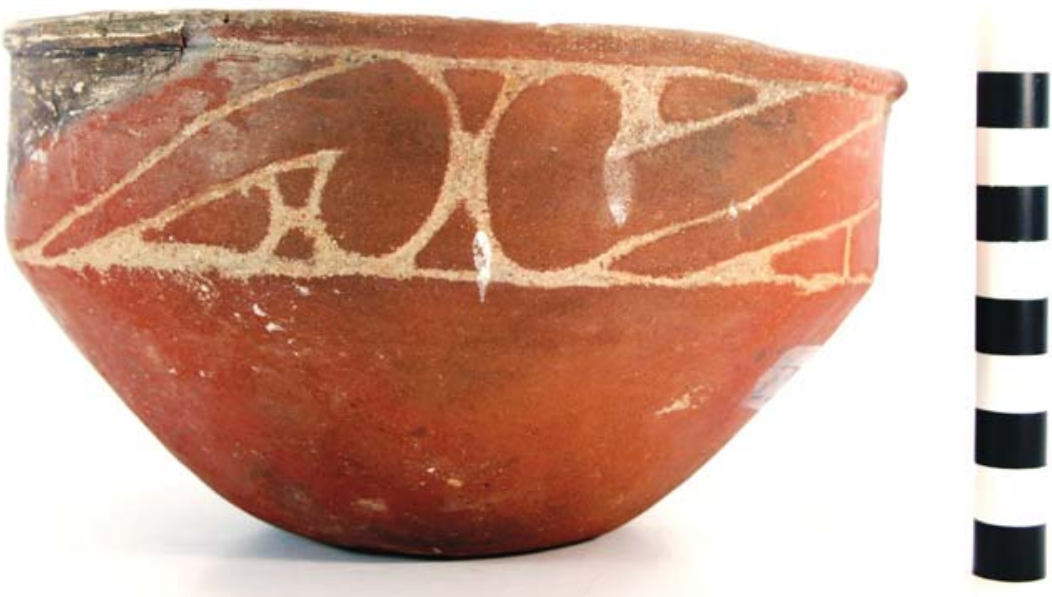

Figure 24. Ripley Engraved, var. Gandy carinated bowl in Burial 3 at the J. H. Reese site (41WD2).

DIAMETER AT BOTTOM OF

RIM OR NECK (IN CM): 17.6

BASE DIAMETER (IN CM) AND SHAPE OF BASE: 7.0; circular and flat

ESTIMATED VOLUME (IN LITERS): 0.9

DECORATION (INCLUDING MOTIF AND ELEMENTS WHEN APPARENT): The interior and exterior vessel surfaces have a red clay slip. On the exterior rim panel is a slanted engraved scroll motif repeated four times around the vessel. The scrolls are divided by excised brackets with upper and lower negative triangle elements. The upper and lower scroll fill zones have excised brackets and triangle elements; the excised bracket in one of the lower scroll fill zones also has upper and lower negative triangle elements (Figure 24).

PIGMENT USE AND LOCATION ON VESSEL: none

TYPE AND VARIETY (IF KNOWN): Ripley Engraved, var. Gandy 
SITE NAME OR SITE NUMBER: J. H. Reese

VESSEL NO.: 26, Burial 3

VESSEL FORM: Carinated bowl

NON-PLASTICS AND PASTE: grog

RIM AND LIP FORM: Direct rim and rounded, exterior folded lip

CORE COLOR: F (fired in a reducing environment and cooled in the open air)

INTERIOR SURFACE COLOR: brown; fire clouds on the rim

EXTERIOR SURFACE COLOR: brown; fire clouds on the rim, body, and base

WALL THICKNESS

(IN MM): rim, $5.9 \mathrm{~mm}$

INTERIOR SURFACE

TREATMENT: smoothed

EXTERIOR SURFACE

TREATMENT: smoothed

HEIGHT (IN CM): 9.5

ORIFICE DIAMETER

(IN CM): 19.5

DIAMETER AT BOTTOM OF

RIM OR NECK (IN CM): 19.3

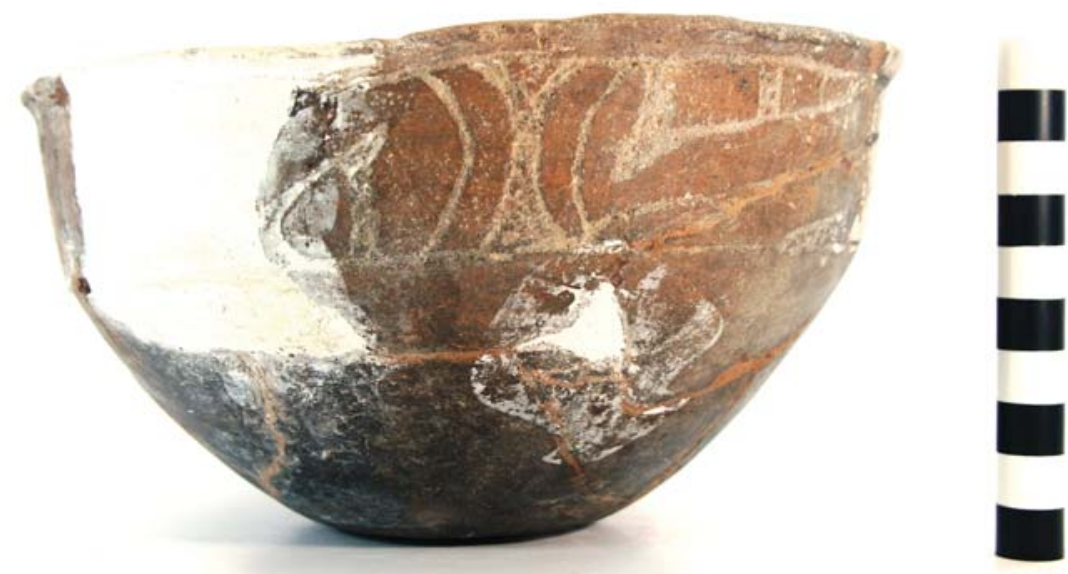

Figure 25. Ripley Engraved, var. Gandy carinated bowl in Burial 3 at the J. H. Reese site (41WD2).

BASE DIAMETER (IN CM) AND

SHAPE OF BASE: 8.0; circular and flat

ESTIMATED VOLUME (IN LITERS): 1.1

DECORATION (INCLUDING MOTIF AND ELEMENTS WHEN APPARENT): The rim panel has an engraved slanted and curvilinear scroll motif repeated four times around the vessel. The scrolls are divided from each other by brackets filled with cross-hatched lines. The upper and lower scroll fill zones have excised brackets and two cross-hatched engraved columns; these outline two negative ovals in each scroll fill zone (Figure 25).

PIGMENT USE AND LOCATION ON VESSEL: none

TYPE AND VARIETY (IF KNOWN): Ripley Engraved, var. Gandy 
SITE NAME OR SITE NUMBER: J. H. Reese

VESSEL NO.: 27, Burial 3

VESSEL FORM: Jar with two loop handles (28 x $10 \mathrm{~mm}$ in height and width) (Figure 26)

NON-PLASTICS AND PASTE: grog

RIM AND LIP FORM: Direct rim and rounded, exterior folded lip

CORE COLOR: $\mathrm{F}$ (fired in a reducing environment and cooled in the open air)

INTERIOR SURFACE COLOR: red

EXTERIOR SURFACE COLOR: red

WALL THICKNESS (IN MM):

rim, $5.2 \mathrm{~mm}$

INTERIOR SURFACE

TREATMENT: burnished

EXTERIOR SURFACE

TREATMENT: burnished

HEIGHT (IN CM): 13.3

ORIFICEDIAMETER(INCM): 10.8

DIAMETER AT BOTTOM OF

RIM OR NECK (IN CM): 10.6

BASE DIAMETER (IN CM)

AND SHAPE OF BASE: 5.7;

circular and flat

ESTIMATED VOLUME

(IN LITERS): 0.9
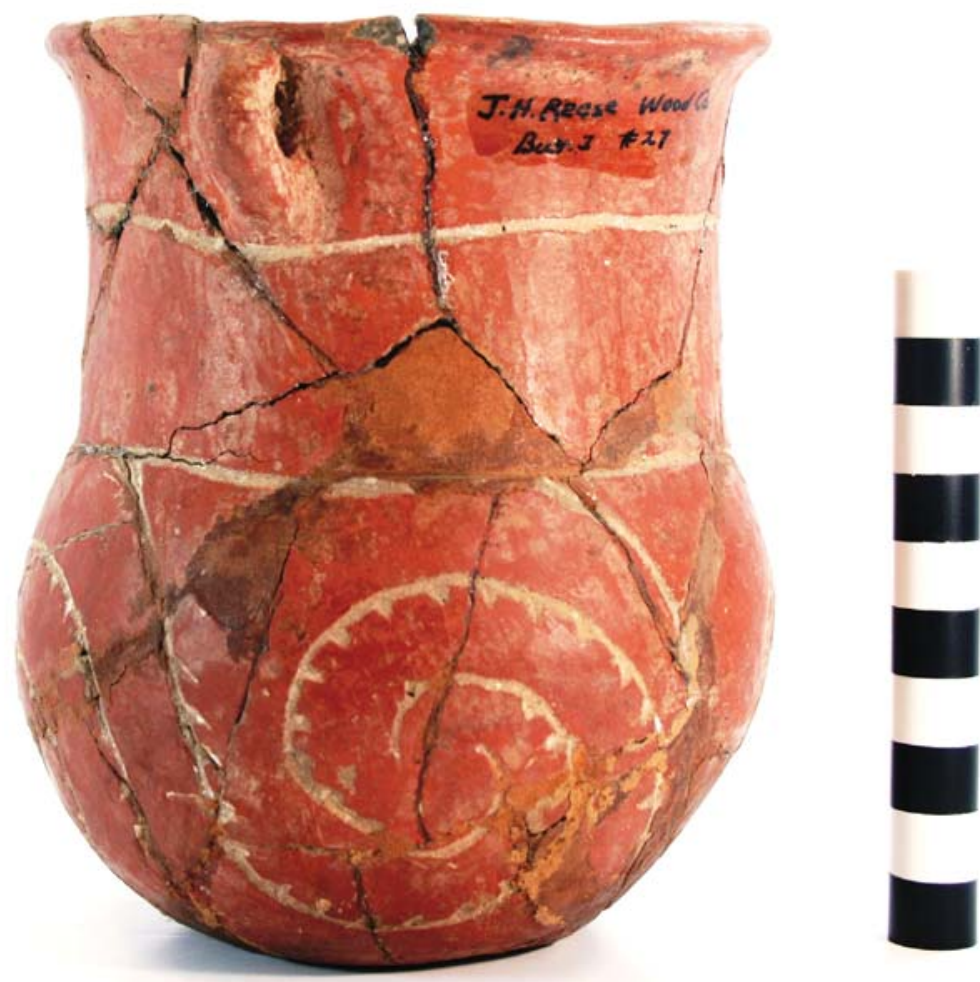

Figure 26. Wilder Engraved, var. unspecified jar in Burial 3 at the J. H. Reese site (41WD2).

DECORATION (INCLUDING MOTIF AND ELEMENTS WHEN APPARENT): The vessel rim has two widely-spaced horizontal engraved lines. The vessel body has four sets of curvilinear engraved lines that wrap around each other and end in hooked arms that do not meet. The lower curvilinear engraved line begins at the apex of a large open pendant triangle; the upper curvilinear engraved line meets the lower horizontal engraved line at the rim-body juncture. The outer curvilinear lines of the motif have small pendant excised triangles on them (Figure 26).

PIGMENT USE AND LOCATION ON VESSEL: white clay pigment in the engraved lines

TYPE AND VARIETY (IF KNOWN): Wilder Engraved, var. unspecified 
SITE NAME OR SITE NUMBER: J. H. Reese

VESSEL NO.: Extra-1

VESSEL FORM: Compound bowl

NON-PLASTICS AND PASTE: grog

RIM AND LIP FORM: Everted rim and rounded lip

CORE COLOR: B (fired and cooled in a reducing environment)

INTERIOR SURFACE

COLOR: grayish-brown

EXTERIOR SURFACE

COLOR: dark grayish-brown

WALL THICKNESS

(IN MM): rim, $4.2 \mathrm{~mm}$

INTERIOR SURFACE

TREATMENT: burnished

EXTERIOR SURFACE

TREATMENT: burnished

HEIGHT (IN CM): 8.9

ORIFICE DIAMETER

(IN CM): 13.0

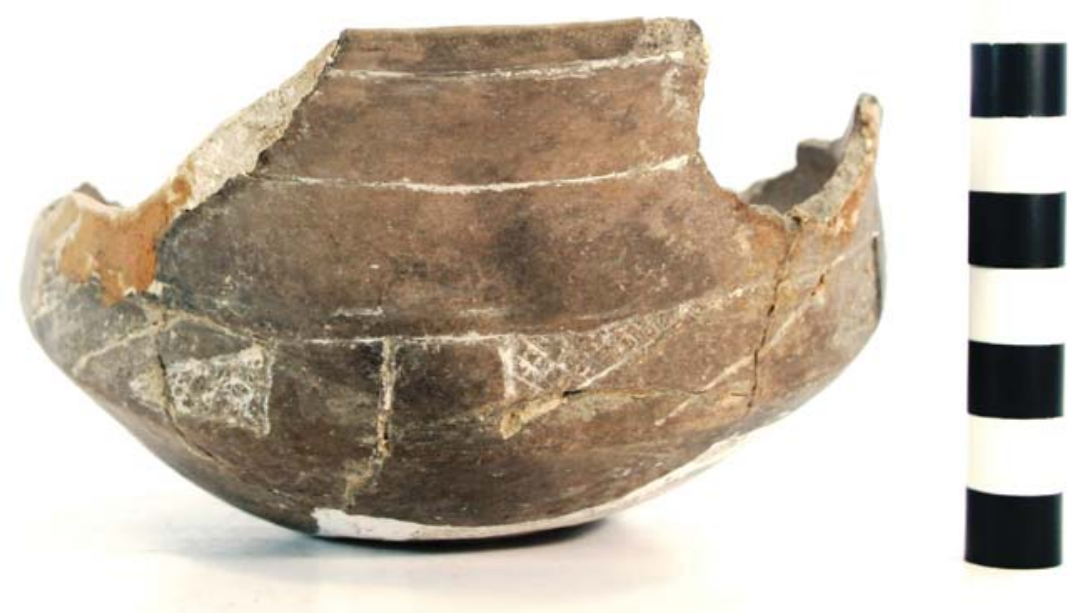

Figure 27. Turner Engraved, var. Turner compound bowl from the J.

DIAMETER AT BOTTOM OF H. Reese site (41WD2).

RIM OR NECK (IN CM): 13.1

BASE DIAMETER (IN CM) AND SHAPE OF BASE: 6.4; circular and flat

ESTIMATED VOLUME (IN LITERS): 0.9

DECORATION (INCLUDING MOTIF AND ELEMENTS WHEN APPARENT): The upper rim panel has three equally-spaced horizontal engraved lines. The lower rim panel has a series of large alternating pendant triangle elements that are either excised or filled with cross-hatched engraved lines. Between these triangle elements are an alternating series of single diagonal or vertical engraved lines (Figure 27).

PIGMENT USE AND LOCATION ON VESSEL: white clay pigment in the engraved lines

TYPE AND VARIETY (IF KNOWN): Turner Engraved, var. Turner (Perttula et al. 2012:Figure 8a) 


\section{H. D. Spigner Site (41WD4) Vessel Documentation}

The H. D. Spigner site is an ancestral Caddo habitation area with two midden deposits and a small cemetery on an upland landform in the Dry Creek basin, not far from the Lake Quitman dam. There are two other ancestral Caddo cemeteries on the same landform: 41WD60 (Cast et al. 2006) and 41WD244 (Perttula et al. 2007), and all three sites may be culturally related.

M. M. Reese excavated five burials at the H. D. Spigner site in May 1931 (Reese 1931). Two of the burials had earlier been exposed by plowing, then the landowners began digging and disturbing the burials. Mr. Reese, a local school teacher, visited the site and attempted to more carefully excavate the burials and recover information about them. The burials were situated next to a midden deposit and they were oriented east-west, with the heads of the deceased at the eastern end of the burials, looking west. In addition to the ceramic vessels placed in the grave as funerary offerings, a ceramic pipe was among the funerary offerings in Burial 2.

SITE NAME OR SITE NUMBER: H. D. Spigner

VESSEL NO.: 1

VESSEL FORM: Bottle with a carinated body and a collared neck

NON-PLASTICS AND PASTE: grog

RIM AND LIP FORM: Direct rim and a rounded lip

CORE COLOR: $\mathrm{F}$ (fired in a reducing environment and cooled in the open air)

INTERIOR SURFACE

COLOR: yellowish-brown

EXTERIOR SURFACE

COLOR: yellowish-brown; fire clouds on the neck

WALL THICKNESS (IN MM): rim, $4.5 \mathrm{~mm}$

INTERIOR SURFACE TREATMENT: none

EXTERIOR SURFACE TREATMENT: smoothed

HEIGHT (IN CM): 23.2

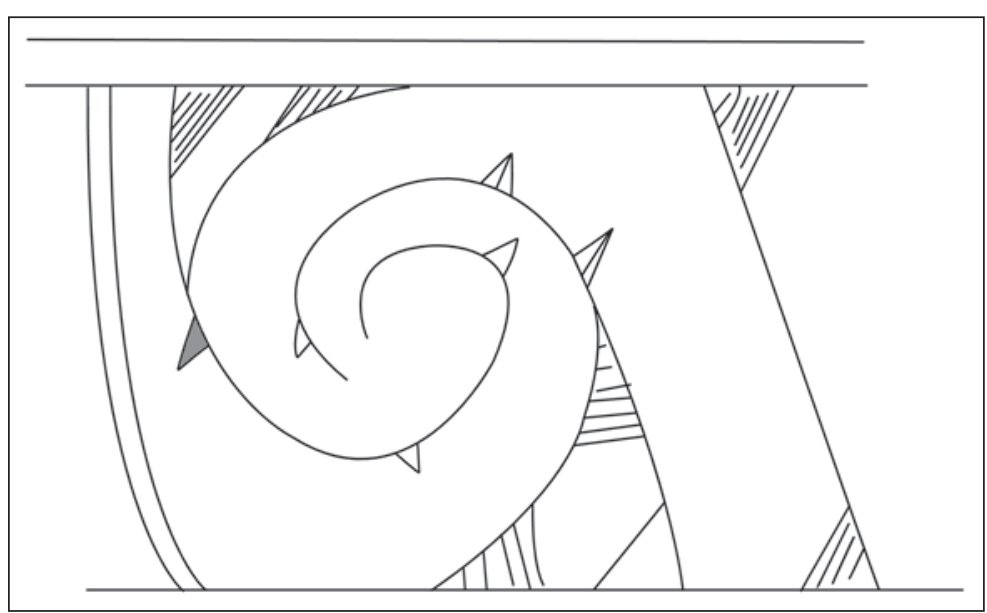

Figure 28. Decorative elements on an engraved bottle from the $\mathrm{H}$. D. Spigner site (41WD4).

ORIFICE DIAMETER (IN CM): 5.0

DIAMETER AT BOTTOM OF RIM OR NECK (IN CM): 7.1; maximum body diameter is $14.7 \mathrm{~cm}$.

BASE DIAMETER (IN CM) AND SHAPE OF BASE: 7.2; circular and flat

ESTIMATED VOLUME (IN LITERS): 0.7 
DECORATION (INCLUDING MOTIF AND ELEMENTS WHEN APPARENT): The upper part of the vessel body has a single horizontal engraved line below the vessel collar and a second horizontal engraved line above the body carination. Between these horizontal engraved lines are three sets of upper and lower curvilinear engraved lines that hook around one another; there are open and hatched pendant triangles on these lines. The curvilinear engraved lines begin at the apex of large upper and lower pendant triangles with hatched corners. These repeated motifs are divided by sets of two nearly vertical engraved lines or a single diagonal engraved line with upper and lower hatched pendant triangles (Figure 28).

PIGMENT USE AND LOCATION ON VESSEL: none

TYPE AND VARIETY (IF KNOWN): Unidentified fine ware

SITE NAME OR SITE NUMBER: H. D. Spigner

VESSEL NO.: 2

VESSEL FORM: Bowl

NON-PLASTICS AND PASTE: grog

RIM AND LIP FORM: Missing

CORE COLOR: $\mathrm{F}$ (fired in a reducing environment and cooled in the open air)

INTERIOR SURFACE COLOR: yellowish-brown; fire clouds on the body

EXTERIOR SURFACE COLOR: reddish-brown; fire clouds on the body and base

WALL THICKNESS (IN MM): body, $6.1 \mathrm{~mm}$

INTERIOR SURFACE TREATMENT: smoothed

EXTERIOR SURFACE TREATMENT: smoothed

HEIGHT (IN CM): 6.0+

ORIFICE DIAMETER (IN CM): N/A

DIAMETER AT BOTTOM OF RIM OR NECK (IN CM): N/A

BASE DIAMETER (IN CM) AND SHAPE OF BASE: 5.8; circular and flat

ESTIMATED VOLUME (IN LITERS): N/A

DECORATION (INCLUDING MOTIF AND ELEMENTS WHEN APPARENT): Plain

PIGMENT USE AND LOCATION ON VESSEL: none

TYPE AND VARIETY (IF KNOWN): Unidentified plain ware 
SITE NAME OR SITE NUMBER: H. D. Spigner

VESSEL NO.: 3

VESSEL FORM: Bowl

NON-PLASTICS AND PASTE: grog

RIM AND LIP FORM: Missing

CORE COLOR: F (fired in a reducing environment and cooled in the open air)

INTERIOR SURFACE COLOR: yellowish-brown

EXTERIOR SURFACE COLOR: reddish-brown

WALL THICKNESS (IN MM): body, $4.4 \mathrm{~mm}$; base, $7.7 \mathrm{~mm}$

INTERIOR SURFACE TREATMENT: smoothed

EXTERIOR SURFACE TREATMENT: smoothed

HEIGHT (IN CM): 6.5+

ORIFICE DIAMETER (IN CM): N/A

DIAMETER AT BOTTOM OF RIM OR NECK (IN CM): N/A

BASE DIAMETER (IN CM) AND SHAPE OF BASE: 7.0; circular and flat

ESTIMATED VOLUME (IN LITERS): N/A

DECORATION (INCLUDING MOTIF AND ELEMENTS WHEN APPARENT): Plain

PIGMENT USE AND LOCATION ON VESSEL: none

TYPE AND VARIETY (IF KNOWN): Unidentified plain ware 
SITE NAME OR SITE NUMBER: H. D. Spigner

VESSEL NO.: 4

VESSEL FORM: Carinated bowl

NON-PLASTICS AND PASTE: grog

RIM AND LIP FORM: Direct rim and rounded, exterior folded lip

CORE COLOR: $\mathrm{F}$ (fired in a reducing environment and cooled in the open air)

INTERIOR SURFACE COLOR: brown

EXTERIOR SURFACE COLOR: brown; fire clouds on the rim and body

WALL THICKNESS (IN MM): rim, $5.2 \mathrm{~mm}$

INTERIOR SURFACE TREATMENT: smoothed

EXTERIOR SURFACE TREATMENT: smoothed

HEIGHT (IN CM): 7.8

ORIFICE DIAMETER (IN CM): 15.7

DIAMETER AT BOTTOM OF RIM OR NECK (IN CM): 15.7

BASE DIAMETER (IN CM) AND SHAPE OF BASE: 7.2; circular and flat

ESTIMATED VOLUME (IN LITERS): 0.8

DECORATION (INCLUDING MOTIF AND ELEMENTS WHEN APPARENT): The vessel is decorated with a continuous series of 56 small hatched pendant engraved triangles underneath the vessel lip (Figure 29).

PIGMENT USE AND LOCATION ON VESSEL: none

TYPE AND VARIETY (IF KNOWN): Unidentified fine ware, cf. Sanders Engraved

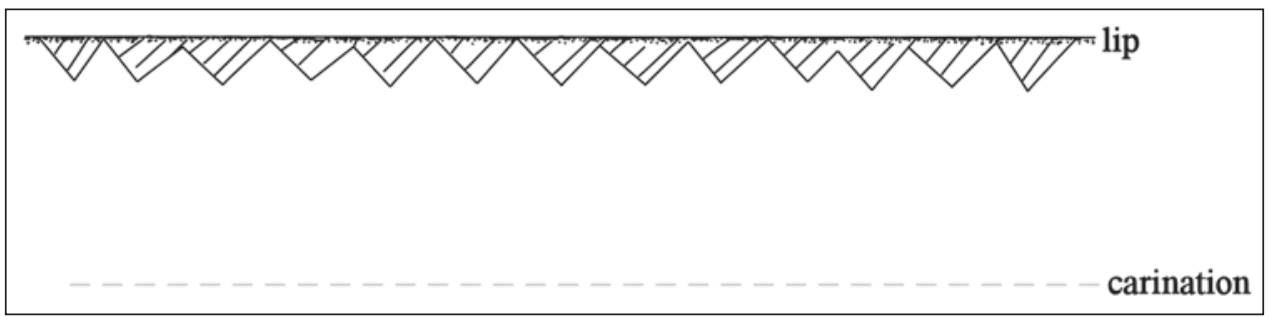

Figure 29. Decorative elements on a cf. Sanders Engraved carinated bowl from the H. D. Spigner site (41WD4). 
SITE NAME OR SITE NUMBER: H. D. Spigner

VESSEL NO.: 5

VESSEL FORM: Compound bowl

NON-PLASTICS AND PASTE: grog

RIM AND LIP FORM: Missing

CORE COLOR: B (fired and cooled in a reducing environment)

INTERIOR SURFACE COLOR: grayish-brown

EXTERIOR SURFACE COLOR: grayish-brown; fire clouds on the body

WALL THICKNESS (IN MM): lower rim, $4.6 \mathrm{~mm}$; body, $5.5 \mathrm{~mm}$

INTERIOR SURFACE TREATMENT: smoothed

EXTERIOR SURFACE TREATMENT: burnished

HEIGHT (IN CM): 7.0+

ORIFICE DIAMETER (IN CM): N/A

DIAMETER AT BOTTOM OF RIM OR NECK (IN CM): 10.2

BASE DIAMETER (IN CM) AND SHAPE OF BASE: 8.3; circular and flat

ESTIMATED VOLUME (IN LITERS): 0.6+

DECORATION (INCLUDING MOTIF AND ELEMENTS WHEN APPARENT): Plain

PIGMENT USE AND LOCATION ON VESSEL: none

TYPE AND VARIETY (IF KNOWN): Unidentified plain ware 
SITE NAME OR SITE NUMBER: H. D. Spigner

VESSEL NO.: 6

VESSEL FORM: Carinated bowl

NON-PLASTICS AND PASTE: grog

RIM AND LIP FORM: Direct rim and rounded lip

CORE COLOR: A (fired and cooled in an oxidizing environment)

INTERIOR SURFACE COLOR: reddish-brown; fire clouds on the body and base

EXTERIOR SURFACE COLOR: reddish-brown; fire clouds on the body and base

WALL THICKNESS (IN MM): rim, $5.2 \mathrm{~mm}$

INTERIOR SURFACE TREATMENT: smoothed

EXTERIOR SURFACE TREATMENT: burnished

HEIGHT (IN CM): 7.6

ORIFICE DIAMETER (IN CM): 15.2

DIAMETER AT BOTTOM OF RIM OR NECK (IN CM): 15.0

BASE DIAMETER (IN CM) AND SHAPE OF BASE: 7.6; circular and flat

ESTIMATED VOLUME (IN LITERS): 0.7

DECORATION (INCLUDING MOTIF AND ELEMENTS WHEN APPARENT): The rim is decorated with a continuous series of 63 hatched engraved pendant triangle elements beneath the vessel lip (Figure 30).

PIGMENT USE AND LOCATION ON VESSEL: none

TYPE AND VARIETY (IF KNOWN): Unidentified fine ware, cf. Sanders Engraved

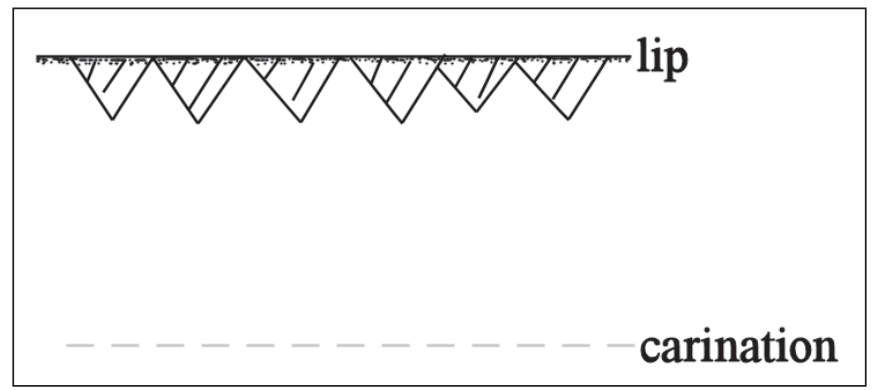

Figure 30. Decorative elements on a cf. Sanders Engraved carinated bowl from the H. D. Spigner site (41WD4). 
SITE NAME OR SITE NUMBER: H. D. Spigner

VESSEL NO.: 7

VESSEL FORM: Carinated bowl with cf. Redwine mode lip (Walters 2010)

NON-PLASTICS AND PASTE: grog

RIM AND LIP FORM: Direct rim and flat, folded out lip

CORE COLOR: F (fired in a reducing environment and cooled in the open air)

INTERIOR SURFACE COLOR: yellowish-brown; fire clouds on the base

EXTERIOR SURFACE COLOR: yellowish-brown; fire clouds on the base

WALL THICKNESS (IN MM): rim, $5.1 \mathrm{~mm}$

INTERIOR SURFACE TREATMENT: smoothed

EXTERIOR SURFACE TREATMENT: smoothed

HEIGHT (IN CM): 3.1

ORIFICE DIAMETER (IN CM): 6.4

DIAMETER AT BOTTOM OF RIM OR NECK (IN CM): 6.4

BASE DIAMETER (IN CM) AND SHAPE OF BASE: 4.0; circular and flat

ESTIMATED VOLUME (IN LITERS): 0.1

DECORATION (INCLUDING MOTIF AND ELEMENTS WHEN APPARENT): The vessel lip is notched, but the remainder of the vessel is undecorated.

PIGMENT USE AND LOCATION ON VESSEL: none

TYPE AND VARIETY (IF KNOWN): Unidentified plain ware 
SITE NAME OR SITE NUMBER: H. D. Spigner

VESSEL NO.: 8

VESSEL FORM: Bowl

NON-PLASTICS AND PASTE: grog

RIM AND LIP FORM: Direct rim and rounded lip

CORE COLOR: F (fired in a reducing environment and cooled in the open air)

INTERIOR SURFACE COLOR: reddish-brown; fire clouds on the base

EXTERIOR SURFACE COLOR: reddish-brown; fire clouds on the rim and base

WALL THICKNESS (IN MM): rim, 4.6 mm

INTERIOR SURFACE TREATMENT: smoothed

EXTERIOR SURFACE TREATMENT: smoothed

HEIGHT (IN CM): 6.0

ORIFICE DIAMETER (IN CM): 11.0

DIAMETER AT BOTTOM OF RIM OR NECK (IN CM): N/A

BASE DIAMETER (IN CM) AND SHAPE OF BASE: 5.5; circular and flat

ESTIMATED VOLUME (IN LITERS): 0.3

DECORATION (INCLUDING MOTIF AND ELEMENTS WHEN APPARENT): Plain

PIGMENT USE AND LOCATION ON VESSEL: none

TYPE AND VARIETY (IF KNOWN): Unidentified plain ware 
SITE NAME OR SITE NUMBER: H. D. Spigner

VESSEL NO.: 9

VESSEL FORM: Jar with four sets of three contiguous lip tabs

NON-PLASTICS AND PASTE: grog

RIM AND LIP FORM: Everted rim and rounded lip

CORE COLOR: G (fired in a reducing environment and cooled in the open air)

INTERIOR SURFACE COLOR: dark grayish-brown

EXTERIOR SURFACE COLOR: yellowish-brown; fire clouds on the rim, body, and base

WALL THICKNESS (IN MM): rim, $5.5 \mathrm{~mm}$

INTERIOR SURFACE TREATMENT: smoothed

EXTERIOR SURFACE TREATMENT: smoothed on the body

HEIGHT (IN CM): 13.3

ORIFICE DIAMETER (IN CM): 13.3

DIAMETER AT BOTTOM OF RIM OR NECK (IN CM): 13.0

BASE DIAMETER (IN CM) AND SHAPE OF BASE: 5.7; circular and flat

ESTIMATED VOLUME (IN LITERS): 1.1

DECORATION (INCLUDING MOTIF AND ELEMENTS WHEN APPARENT): The vessel rim is decorated with cross-hatched incised lines. There is also a single row of tool punctations at the top of the vessel body, immediately below the rim-body juncture (Figure 31).

PIGMENT USE AND LOCATION ON VESSEL: none

TYPE AND VARIETY (IF KNOWN): Canton Incised

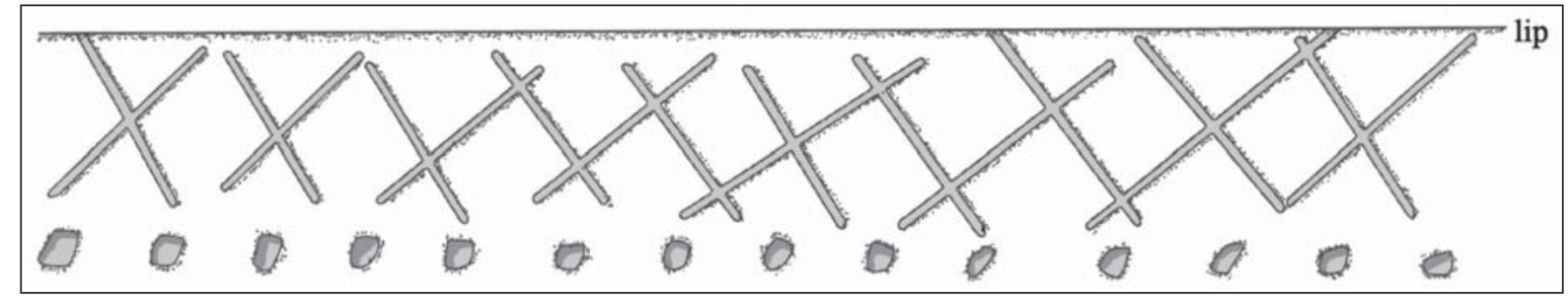

Figure 31. Decorative elements on a Canton Incised jar from the H. D. Spigner site (41WD4). 
SITE NAME OR SITE NUMBER: H. D. Spigner

VESSEL NO.: 10

VESSEL FORM: Bottle

NON-PLASTICS AND PASTE: grog

RIM AND LIP FORM: Direct rim and rounded lip

CORE COLOR: B (fired and cooled in a reducing environment)

INTERIOR SURFACE COLOR: grayish-brown

EXTERIOR SURFACE COLOR: grayish-brown; fire clouds on the body and base

WALL THICKNESS (IN MM): rim, $5.2 \mathrm{~mm}$

INTERIOR SURFACE TREATMENT: none

EXTERIOR SURFACE TREATMENT: smoothed

HEIGHT (IN CM): 14.2

ORIFICE DIAMETER (IN CM): 3.5

DIAMETER AT BOTTOM OF RIM OR NECK (IN CM): 3.7 ; maximum body diameter is $8.0 \mathrm{~cm}$.

BASE DIAMETER (IN CM) AND SHAPE OF BASE: 5.3; circular and flat

ESTIMATED VOLUME (IN LITERS): 0.3

DECORATION (INCLUDING MOTIF AND ELEMENTS WHEN APPARENT): Plain

PIGMENT USE AND LOCATION ON VESSEL: none

TYPE AND VARIETY (IF KNOWN): Unidentified plain ware 
SITE NAME OR SITE NUMBER: H. D. Spigner

VESSEL NO.: 11

VESSEL FORM: Jar

NON-PLASTICS AND PASTE: grog

RIM AND LIP FORM: Direct rim and rounded, exterior folded lip

CORE COLOR: F (fired in a reducing environment and cooled in the open air)

INTERIOR SURFACE COLOR: reddish-brown; fire clouds on the rim and body

EXTERIOR SURFACE COLOR: yellowish-brown; fire clouds on the rim and body; organic residue on the rim and body

WALL THICKNESS (IN MM): rim, $5.8 \mathrm{~mm}$

INTERIOR SURFACE TREATMENT: smoothed

EXTERIOR SURFACE TREATMENT: none

HEIGHT (IN CM): 13.5

ORIFICE DIAMETER (IN CM): 11.8

DIAMETER AT BOTTOM OF RIM OR NECK (IN CM): 11.8

BASE DIAMETER (IN CM) AND SHAPE OF BASE: 8.0; circular and flat

ESTIMATED VOLUME (IN LITERS): 1.0

DECORATION (INCLUDING MOTIF AND ELEMENTS WHEN APPARENT): The vessel lip is decorated with a row of diagonal tool punctations. The remainder of the rim and the body (to within $4.0 \mathrm{~cm}$ of the vessel body) has vertical brushing marks.

PIGMENT USE AND LOCATION ON VESSEL: none

TYPE AND VARIETY (IF KNOWN): Bullard Brushed 
SITE NAME OR SITE NUMBER: H. D. Spigner

VESSEL NO.: 12

VESSEL FORM: Jar

NON-PLASTICS AND PASTE: grog

RIM AND LIP FORM: Everted rim and rounded lip

CORE COLOR: A (fired and cooled in an oxidizing environment)

INTERIOR SURFACE COLOR: reddish-brown; fire clouds on the rim, body, and base

EXTERIOR SURFACE COLOR: reddish-brown; fire clouds on the body and base

WALL THICKNESS (IN MM): rim, $5.6 \mathrm{~mm}$

INTERIOR SURFACE

TREATMENT: none

EXTERIOR SURFACE

TREATMENT: none

HEIGHT (IN CM): 15.2

ORIFICE DIAMETER

(IN CM): 12.7

DIAMETER AT BOTTOM

OF RIM OR NECK

(IN CM): 12.3

BASE DIAMETER (IN CM) AND SHAPE OF BASE:

7.6; circular and flat

ESTIMATED VOLUME

(IN LITERS): 1.2

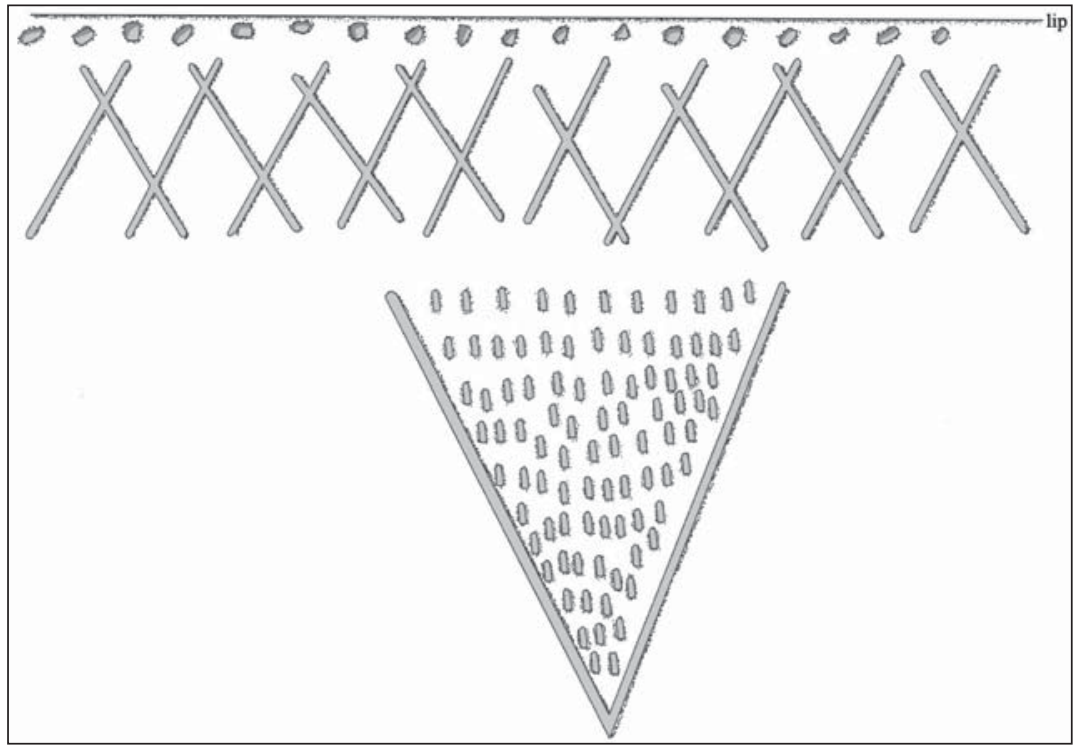

Figure 32. Decorative elements on a Canton Incised jar from the H. D. Spigner site (41WD4).

DECORATION (INCLUDING MOTIF AND ELEMENTS WHEN APPARENT): The vessel rim is decorated with cross-hatched incised lines, and there is a single horizontal row of tool punctations beneath the vessel lip. The vessel body has four large incised triangle elements that reach almost to the vessel base and are filled with rows of linear tool punctations (Figure 32).

PIGMENT USE AND LOCATION ON VESSEL: none

TYPE AND VARIETY (IF KNOWN): Canton Incised 
SITE NAME OR SITE NUMBER: H. D. Spigner

VESSEL NO.: 13

VESSEL FORM: Bottle

NON-PLASTICS AND PASTE: grog

RIM AND LIP FORM: Direct rim and rounded lip

CORE COLOR: B (fired and cooled in a reducing environment)

INTERIOR SURFACE COLOR: grayish-brown

EXTERIOR SURFACE COLOR: grayish-brown; fire clouds on the body

WALL THICKNESS

(IN MM): rim, $4.6 \mathrm{~mm}$

INTERIOR SURFACE

TREATMENT: none

EXTERIOR SURFACE

TREATMENT: smoothed

HEIGHT (IN CM): 14.6

ORIFICE DIAMETER

(IN CM): 4.0

DIAMETER AT BOTTOM

OF RIM OR NECK

(IN CM): 4.9; maximum

body diameter is $10.8 \mathrm{~cm}$.

BASE DIAMETER (IN CM)

AND SHAPE OF BASE: 5.7;

circular and rounded

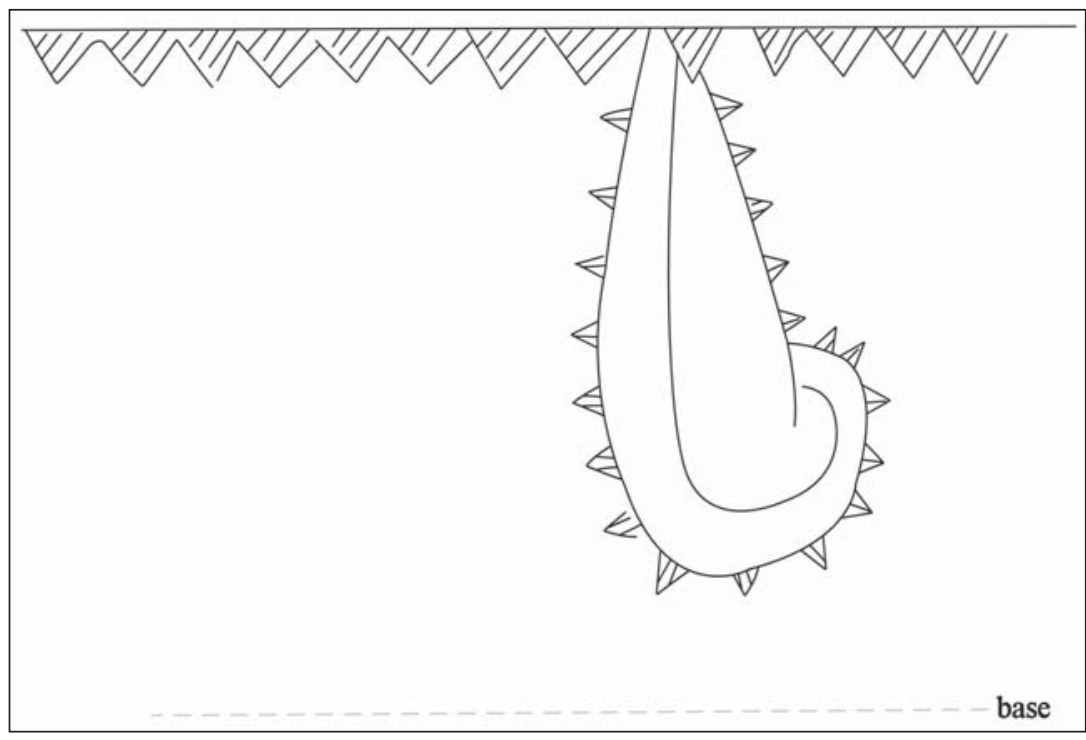

Figure 33. Decorative elements on a cf. Sanders Engraved bottle from the H. D. Spigner site (41WD4).

ESTIMATED VOLUME (IN LITERS): 0.3

DECORATION (INCLUDING MOTIFAND ELEMENTS WHENAPPARENT): The upper part of the vessel body has a single horizontal engraved line with a continuous series of 15 hatched pendant triangle elements. There also are two vertical and curvilinear engraved line elements comprised of three lines that have smaller cross-hatched pendant triangles on the outermost engraved line; one of these vertical and curvilinear engraved line elements has hatched triangles on its middle engraved line (Figure 33).

PIGMENT USE AND LOCATION ON VESSEL: none

TYPE AND VARIETY (IF KNOWN): Unidentified fine ware, cf. Sanders Engraved 
SITE NAME OR SITE NUMBER: H. D. Spigner

VESSEL NO.: 14

VESSEL FORM: Jar

NON-PLASTICS AND PASTE: grog

RIM AND LIP FORM: Everted rim and rounded lip

CORE COLOR: $\mathrm{F}$ (fired in a reducing environment and cooled in the open air)

INTERIOR SURFACE COLOR: yellowish-brown; fire clouds on the rim and body

EXTERIOR SURFACE COLOR: yellowish-brown; fire clouds on the rim, body, and base

WALL THICKNESS (IN MM): rim, $7.1 \mathrm{~mm}$

INTERIOR SURFACE TREATMENT: smoothed

EXTERIOR SURFACE TREATMENT: smoothed on the body

HEIGHT (IN CM): 11.0

ORIFICE DIAMETER (IN CM): 13.0

DIAMETER AT BOTTOM OF RIM OR NECK (IN CM): 11.8

BASE DIAMETER (IN CM) AND SHAPE OF BASE: 7.0; circular and flat

ESTIMATED VOLUME (IN LITERS): 0.9

DECORATION (INCLUDING MOTIF AND ELEMENTS WHEN APPARENT): The rim is decorated with eight horizontal rows of tool punctations.

PIGMENT USE AND LOCATION ON VESSEL: none

TYPE AND VARIETY (IF KNOWN): Unidentified utility ware 
SITE NAME OR SITE NUMBER: H. D. Spigner

VESSEL NO.: 15

VESSEL FORM: Carinated bowl with lip tabs

NON-PLASTICS AND PASTE: grog

RIM AND LIP FORM: Direct rim and rounded, exterior flattened lip

CORE COLOR: F (fired in a reducing environment and cooled in the open air)

INTERIOR SURFACE COLOR: brown

EXTERIOR SURFACE COLOR: brown

WALL THICKNESS (IN MM): rim, $5.9 \mathrm{~mm}$

INTERIOR SURFACE TREATMENT: smoothed

EXTERIOR SURFACE TREATMENT: smoothed

HEIGHT (IN CM): 9.5

ORIFICE DIAMETER (IN CM): 15.2

DIAMETER AT BOTTOM OF RIM OR NECK (IN CM): 15.0

BASE DIAMETER (IN CM) AND SHAPE OF BASE: 7.6; circular and flat

ESTIMATED VOLUME (IN LITERS): 0.9

DECORATION (INCLUDING MOTIF AND ELEMENTS WHEN APPARENT): The rim is decorated with six narrow diagonal engraved zones filled with diagonal lines (i.e., ladders). At the top of the rim and between the diagonal engraved zones are a series of six large pendant triangles filled with diagonal engraved lines (Figure 34).

PIGMENT USE AND LOCATION ON VESSEL: red clay pigment in the engraved lines

TYPE AND VARIETY (IF KNOWN): Unidentified fine ware, cf. Sanders Engraved

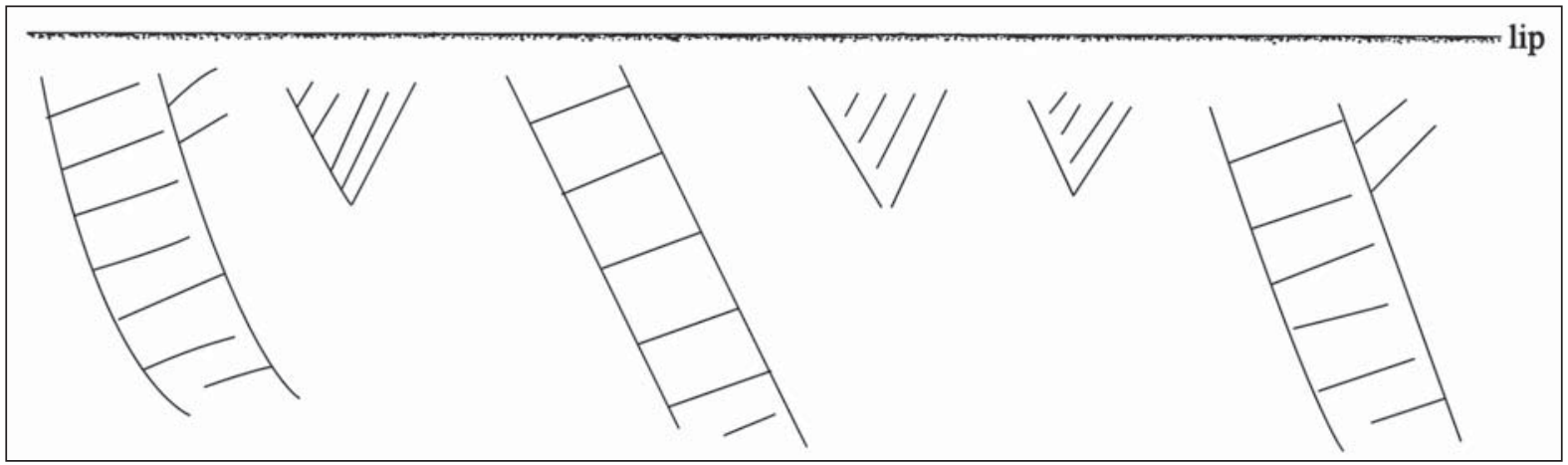

Figure 34. Decorative elements on a cf. Sanders Engraved carinated bowl from the H. D. Spigner site (41WD4). 
SITE NAME OR SITE NUMBER: H. D. Spigner

VESSEL NO.: 16

VESSEL FORM: Compound bowl

NON-PLASTICS AND PASTE: grog

RIM AND LIP FORM: Everted rim and rounded lip

CORE COLOR: F (fired in a reducing environment and cooled in the open air)

INTERIOR SURFACE COLOR: brown

EXTERIOR SURFACE COLOR: brown; fire clouds on the body and base

WALL THICKNESS (IN MM): rim, $5.2 \mathrm{~mm}$

INTERIOR SURFACE TREATMENT: smoothed

EXTERIOR SURFACE TREATMENT: smoothed

HEIGHT (IN CM): 7.8

ORIFICE DIAMETER (IN CM): 12.5

DIAMETER AT BOTTOM OF RIM OR NECK (IN CM): 11.0

BASE DIAMETER (IN CM) AND SHAPE OF BASE: 7.0; circular and flat

ESTIMATED VOLUME (IN LITERS): 0.8

DECORATION (INCLUDING MOTIF AND ELEMENTS WHEN APPARENT): Plain

PIGMENT USE AND LOCATION ON VESSEL: none

TYPE AND VARIETY (IF KNOWN): Unidentified plain ware 
SITE NAME OR SITE NUMBER: H. D. Spigner

VESSEL NO.: 17

VESSEL FORM: Bowl

NON-PLASTICS AND PASTE: grog

RIM AND LIP FORM: Direct rim and rounded lip

CORE COLOR: $\mathrm{F}$ (fired in a reducing environment and cooled in the open air)

INTERIOR SURFACE COLOR: yellowish-brown

EXTERIOR SURFACE COLOR: reddish-brown; fire clouds on the body and base

WALL THICKNESS (IN MM): rim, $6.6 \mathrm{~mm}$

INTERIOR SURFACE TREATMENT: smoothed

EXTERIOR SURFACE TREATMENT: smoothed

HEIGHT (IN CM): 6.4

ORIFICE DIAMETER (IN CM): 13.3

DIAMETER AT BOTTOM OF RIM OR NECK (IN CM): N/A

BASE DIAMETER (IN CM) AND SHAPE OF BASE: 7.0; circular and flat

ESTIMATED VOLUME (IN LITERS): 0.3

DECORATION (INCLUDING MOTIF AND ELEMENTS WHEN APPARENT): The vessel is decorated with four appliqued lugs ( $21 \times 10 \mathrm{~mm}$ in height and width) at the lip and on the rim. One of the lugs has two closely-spaced appliqued ridges ( $13 \times 8 \mathrm{~mm}$ in length and width).

PIGMENT USE AND LOCATION ON VESSEL: none

TYPE AND VARIETY (IF KNOWN): Unidentified utility ware

\section{Mattie Dial Site (41WD5) Vessel Documentation}

The Mattie Dial site was investigated by UT in August 1930 by A. T. Jackson and A. M. Wilson. A single ancestral Caddo burial was excavated at that time, exposed at the depth of ca. $13 \mathrm{~cm}$. The grave was oriented east-west, with the head of the deceased at the eastern end of the grave, and facing west. The site was situated along Big Caney Creek in the Lake Fork Creek drainage basin, and is now under the waters of Lake Fork Reservoir.

SITE NAME OR SITE NUMBER: Mattie Dial

VESSEL NO.: 1, Burial 1 
VESSEL FORM: Bottle

NON-PLASTICS AND PASTE: grog

RIM AND LIP FORM: Direct rim and rounded lip

CORE COLOR: $\mathrm{F}$ (fired in a reducing environment and cooled in the open air)

INTERIOR SURFACE COLOR: red (at the neck)

EXTERIOR SURFACE COLOR: red

WALL THICKNESS (IN MM): rim, $5.8 \mathrm{~mm}$

INTERIOR SURFACE TREATMENT: none

EXTERIOR SURFACE TREATMENT: burnished

HEIGHT (IN CM): 17.2

ORIFICE DIAMETER (IN CM): 4.8

DIAMETER AT BOTTOM OF RIM OR NECK (IN CM): 5.0; maximum body diameter is $11.0 \mathrm{~cm}$

BASE DIAMETER (IN CM) AND SHAPE OF BASE: 7.0; circular and rounded

ESTIMATED VOLUME (IN LITERS): 0.5

DECORATION (INCLUDING MOTIF AND ELEMENTS WHEN APPARENT): the exterior vessel surface has a red slip, as does the interior vessel surface at the neck. The vessel body has two vertical columns of appliqued ridges that extend to within $2.5 \mathrm{~cm}$ of the vessel base.

PIGMENT USE AND LOCATION ON VESSEL: none

TYPE AND VARIETY (IF KNOWN): Maxey Noded Redware

SITE NAME OR SITE NUMBER: Mattie Dial

VESSEL NO.: 3, Burial 1

VESSEL FORM: Bowl with four lip tabs

NON-PLASTICS AND PASTE: grog

RIM AND LIP FORM: Direct rim and rounded lip

CORE COLOR: $\mathrm{F}$ (fired in a reducing environment and cooled in the open air)

INTERIOR SURFACE COLOR: yellowish-brown; fire clouds on the base

EXTERIOR SURFACE COLOR: yellowish-brown; fire clouds on the base 
WALL THICKNESS (IN MM): rim, $5.2 \mathrm{~mm}$

INTERIOR SURFACE TREATMENT: smoothed

EXTERIOR SURFACE TREATMENT: smoothed

HEIGHT (IN CM): 7.5

ORIFICE DIAMETER (IN CM): 12.1

DIAMETER AT BOTTOM OF RIM OR NECK (IN CM): N/A

BASE DIAMETER (IN CM) AND SHAPE OF BASE: 7.6; circular and flat

ESTIMATED VOLUME (IN LITERS): 0.4

DECORATION (INCLUDING MOTIF AND ELEMENTS WHEN APPARENT): Plain

PIGMENT USE AND LOCATION ON VESSEL: none

TYPE AND VARIETY (IF KNOWN): Unidentified plain ware

\section{F. Cathey Site (41WD14) Vessel Documentation}

The B. F. Cathey site was investigated by A. T. Jackson and A. M. Wilson in 1930 (Wilson and Jackson 193), and they identified midden deposits and a cemetery area there. Two pottery vessels were found in a cultivated field at the time, where they had been exposed by plowing. The site is in the Lake Fork Creek basin.

SITE NAME OR SITE NUMBER: B. F. Cathey

VESSEL NO.: 1

VESSEL FORM: Jar with four rim peaks and vertical appliqued lugs on each rim peak

NON-PLASTICS AND PASTE: grog

RIM AND LIP FORM: Everted rim and rounded, exterior folded lip

CORE COLOR: B (fired and cooled in a reducing environment)

INTERIOR SURFACE COLOR: black

EXTERIOR SURFACE COLOR: black

WALL THICKNESS (IN MM): rim, $6.2 \mathrm{~mm}$

INTERIOR SURFACE TREATMENT: smoothed 
EXTERIOR SURFACE TREATMENT: smoothed on the body

HEIGHT (IN CM): 13.5

ORIFICE DIAMETER (IN CM): 10.5

DIAMETER AT BOTTOM OF RIM OR NECK (IN CM): 9.5

BASE DIAMETER (IN CM) AND SHAPE OF BASE: 5.5; circular and flat

ESTIMATED VOLUME (IN LITERS): 0.85

DECORATION (INCLUDING MOTIF AND ELEMENTS WHEN APPARENT): The vessel rim has three horizontal rows of neck bands. The vessel body has four large appliqued ridge triangle elements pendant from the rim-body juncture; each of these elements has either four or six vertical appliqued ridges within them. There are also four vertical appliqued ridges on the vessel body that extend to within $3.0 \mathrm{~cm}$ of the vessel base. These appliqued ridges begin at the base of the appliqued triangle elements (Figure 35).

PIGMENT USE AND LOCATION ON VESSEL: none

TYPE AND VARIETY (IF KNOWN): La Rue Neck Banded

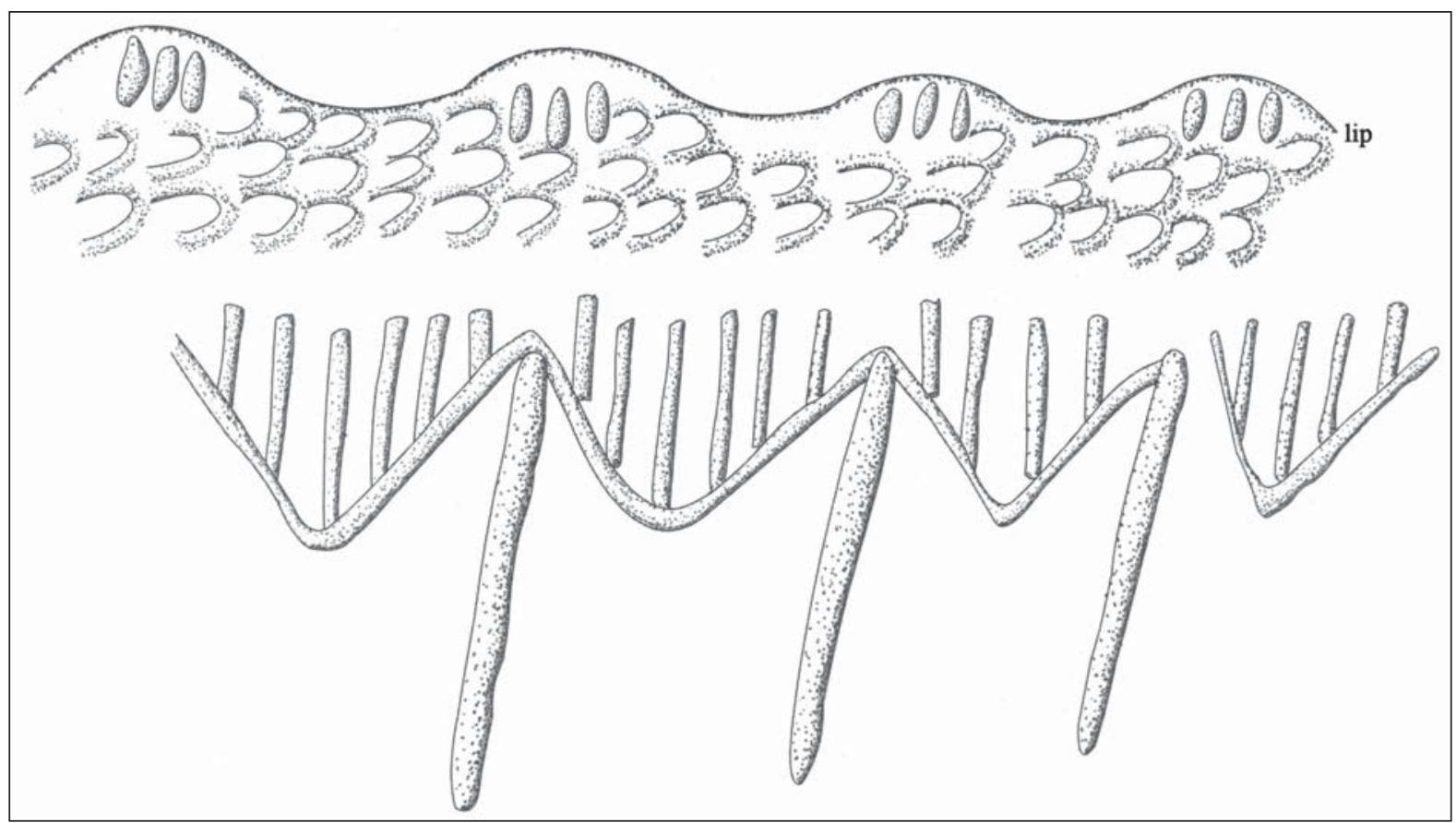

Figure 35. La Rue Neck Banded jar from the B. F. Cathey site (41WD14). 
SITE NAME OR SITE NUMBER: B. F. Cathey

VESSEL NO.: 2

VESSEL FORM: Jar

NON-PLASTICS AND PASTE: grog

RIM AND LIP FORM: Everted rim and rounded lip

CORE COLOR: F (fired in a reducing environment and cooled in the open air)

INTERIOR SURFACE COLOR: brown

EXTERIOR SURFACE COLOR: brown; fire clouds on the body

WALL THICKNESS (IN MM): rim, $7.1 \mathrm{~mm}$; body, $7.9 \mathrm{~mm}$; base, $10.3 \mathrm{~mm}$

INTERIOR SURFACE TREATMENT: smoothed

EXTERIOR SURFACE TREATMENT: smoothed on the body

HEIGHT (IN CM): 8.0+

ORIFICE DIAMETER (IN CM): N/A

DIAMETER AT BOTTOM OF RIM OR NECK (IN CM): N/A

BASE DIAMETER (IN CM) AND SHAPE OF BASE: 9.0; circular and concave

ESTIMATED VOLUME (IN LITERS): N/A

DECORATION (INCLUDING MOTIF AND ELEMENTS WHEN APPARENT): The rim has two horizontal rows of neck bands.

PIGMENT USE AND LOCATION ON VESSEL: none

TYPE AND VARIETY (IF KNOWN): La Rue Neck Banded

\section{J. H. Baker Site (41WD33) Vessel Documentation}

The ancestral Caddo ceramic vessels from the J. H. Baker site were either purchased by A. T. Jackson in 1930, or were collected by him that same year; along with the ceramic vessels were three large marine shell beads and a ground stone celt. A burial had been exposed by a road crew working adjacent to a state highway. The site is in the Dry Creek valley in the upper Sabine River basin.

SITE NAME OR SITE NUMBER: J. H. Baker

VESSEL NO.: 2

VESSEL FORM: Bottle 
NON-PLASTICS AND PASTE: grog

RIM AND LIP FORM: Missing

CORE COLOR: B (fired and cooled in a reducing environment)

INTERIOR SURFACE COLOR: very dark grayish-brown

EXTERIOR SURFACE COLOR: very dark grayish-brown; fire clouds on the body

WALL THICKNESS (IN MM):

body, $5.2 \mathrm{~mm}$

INTERIOR SURFACE

TREATMENT: none

EXTERIOR SURFACE

TREATMENT: burnished

HEIGHT (IN CM): 12.1+

ORIFICE DIAMETER

(IN CM): N/A

DIAMETER AT BOTTOM

OF RIM OR NECK (IN CM): 11.4

BASE DIAMETER (IN CM)

AND SHAPE OF BASE: 6.4 ;

circular and flat

ESTIMATED VOLUME

(IN LITERS): 0.3+

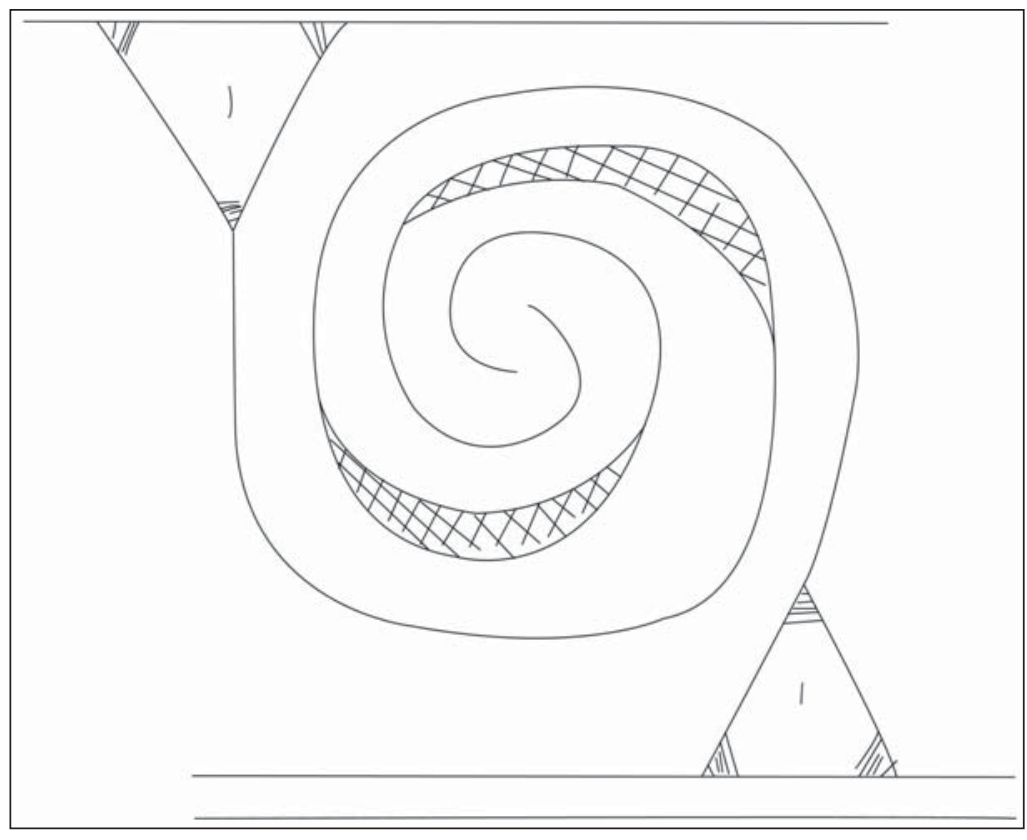

Figure 36. Decorative elements on Wilder Engraved, var. unspecified bottle from the J. H. Baker site (41WD33).

DECORATION (INCLUDING MOTIF AND ELEMENTS WHEN APPARENT): There is a single horizontal engraved line at the top of the vessel body and two horizontal engraved lines above the vessel base. Between these lines are four sets of engraved curvilinear and hooked arm motifs; the hooked arms do not meet. The curvilinear engraved lines begin and end at upper and lower large pendant triangles with excised corners and a central excised dash. Where the curvilinear and hooked arm lines pass each other, each of the lines has a widened area filled with cross-hatched engraved lines (Figure 36).

PIGMENT USE AND LOCATION ON VESSEL: none

TYPE AND VARIETY (IF KNOWN): Wilder Engraved, var. unspecified 
SITE NAME OR SITE NUMBER: J. H. Baker

VESSEL NO.: 3

VESSEL FORM: Bottle with a collared neck and a carinated body

NON-PLASTICS AND PASTE: grog

RIM AND LIP FORM: Missing

CORE COLOR: F (fired in a reducing environment and cooled in the open air)

INTERIOR SURFACE COLOR: yellowish-brown

EXTERIOR SURFACE COLOR: yellowish-brown; fire clouds on the rim, body, and base

WALL THICKNESS (IN MM): rim, $8.1 \mathrm{~mm}$

INTERIOR SURFACE TREATMENT: none

EXTERIOR SURFACE TREATMENT: smoothed

HEIGHT (IN CM): 9.5+

ORIFICE DIAMETER (IN CM): N/A

DIAMETER AT BOTTOM OF RIM OR NECK (IN CM): 7.7

BASE DIAMETER (IN CM) AND SHAPE OF BASE: 5.3; circular and concave

ESTIMATED VOLUME (IN LITERS): 0.2+

DECORATION (INCLUDING MOTIF AND ELEMENTS WHEN APPARENT): The vessel body has six sets of slanting engraved scrolls that end in hooked arm elements. The scroll fill zones are triangular-shaped, either open or with cross-hatched engraved lines (Figure 37).

PIGMENT USE AND LOCATION ON VESSEL: none

TYPE AND VARIETY (IF KNOWN): Taylor Engraved

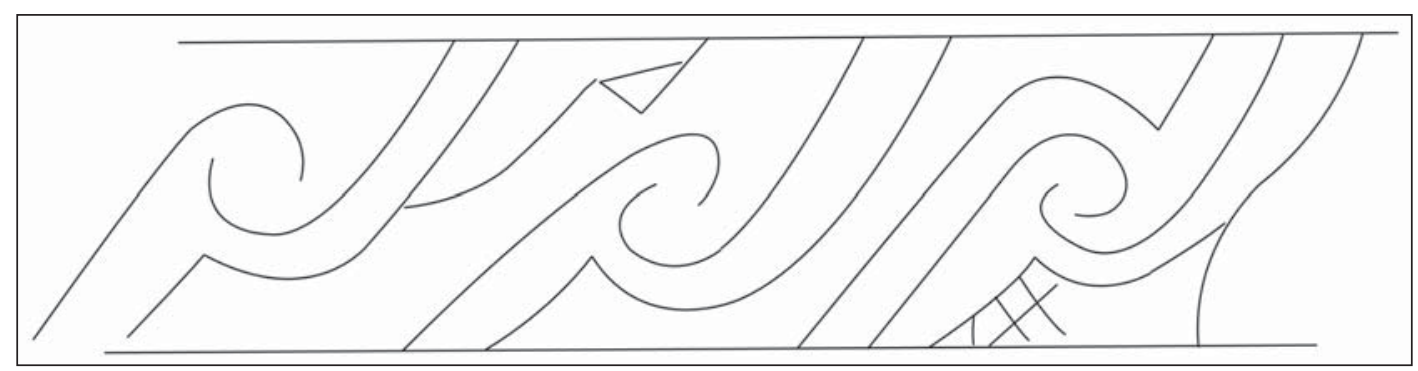

Figure 37. Decorative elements on a Taylor Engraved bottle from the J. H. Baker site (41WD33). 
SITE NAME OR SITE NUMBER: J. H. Baker

VESSEL NO.: 177

VESSEL FORM: Carinated bowl

NON-PLASTICS AND PASTE: grog

RIM AND LIP FORM: Inverted rim and rounded, exterior folded lip

CORE COLOR: F (fired in a reducing environment and cooled in the open air)

INTERIOR SURFACE COLOR: yellowish-brown; fire clouds on the body and base

EXTERIOR SURFACE COLOR: yellowish-brown; fire clouds on the rim, body, and base

WALL THICKNESS (IN MM): rim, 5.9 mm

INTERIOR SURFACE TREATMENT: smoothed

EXTERIOR SURFACE TREATMENT: smoothed

HEIGHT (IN CM): 8.0

ORIFICE DIAMETER (IN CM): 15.2

DIAMETER AT BOTTOM OF RIM OR NECK (IN CM): 15.9

BASE DIAMETER (IN CM) AND SHAPE OF BASE: 7.0; circular and concave

ESTIMATED VOLUME (IN LITERS): 0.7

DECORATION (INCLUDING MOTIF AND ELEMENTS WHEN APPARENT): The rim panel has an engraved slanted scroll motif repeated four times around the vessel. The upper scroll fill zones are large open triangle elements, while the lower scroll fill zones have excised brackets and triangles, creating two negative ovals within each scroll fill zone (Figure 38).

PIGMENT USE AND LOCATION ON VESSEL: none

TYPE AND VARIETY (IF KNOWN): Ripley Engraved, var. Carpenter

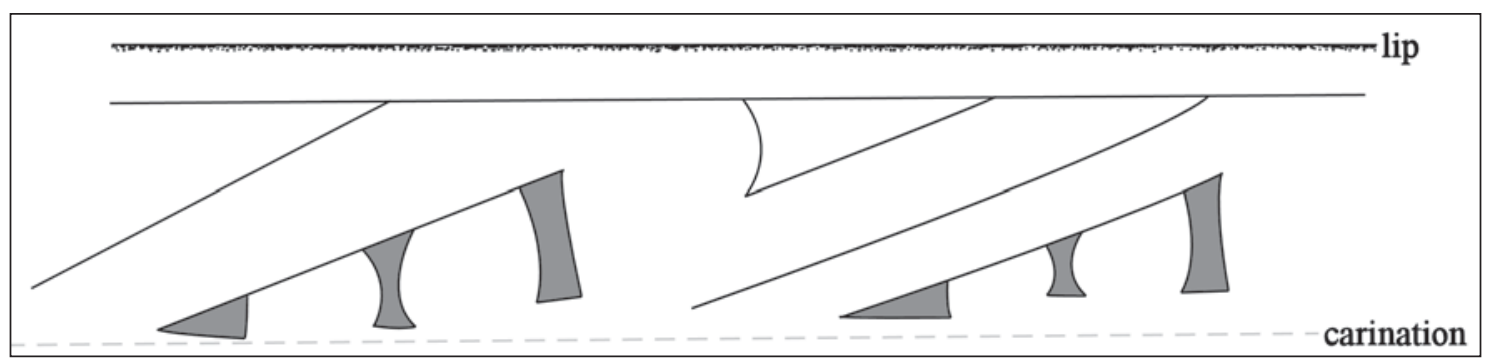

Figure 38. Decorative elements on a Ripley Engraved, var. Carpenter carinated bowl from the J. H. Baker site (41WD33). 
SITE NAME OR SITE NUMBER: J. H. Baker

VESSEL NO.: 178

VESSEL FORM: Bottle

NON-PLASTICS AND PASTE: grog

RIM AND LIP FORM: Missing

CORE COLOR: G (fired in a reducing environment and cooled in the open air)

INTERIOR SURFACE COLOR: grayish-brown

EXTERIOR SURFACE COLOR: red

WALL THICKNESS (IN MM): neck, 6.4 mm

INTERIOR SURFACE TREATMENT: none

EXTERIOR SURFACE TREATMENT: burnished

HEIGHT (IN CM): 19.7+

ORIFICE DIAMETER (IN CM): 5.2

DIAMETER AT BOTTOM OF RIM OR NECK (IN CM): 5.5; maximum body diameter is $12.5 \mathrm{~cm}$.

BASE DIAMETER (IN CM) AND SHAPE OF BASE: 9.5; circular and flat

ESTIMATED VOLUME (IN LITERS): 0.7+

DECORATION (INCLUDING MOTIF AND ELEMENTS WHEN APPARENT): The exterior surface of the vessel has a red clay slip. There are also two vertical columns of three appliqued ridges on the vessel body.

PIGMENT USE AND LOCATION ON VESSEL: none

TYPE AND VARIETY (IF KNOWN): Unidentified fine ware

\section{WD117 Vessel Documentation}

The vessel from 41WD117 was recovered from a probable burial feature exposed in a road cut in the Big Sandy Creek basin (Perttula et al. 1986:337). The vessel was located about $60 \mathrm{~cm}$ below the top of the road cut. Other Caddo vessels have been reported from the site. A thermoluminescence date of ca. A.D. 1280 (Alpha-2398), with a corrected date and age range of A.D. 1213-1347, was obtained on one rim sherd from the vessel (Perttula et al. 1986:338, Perttula et al. 1987:Table 1).

SITE NAME OR SITE NUMBER: 41WD117

VESSEL NO.: A-17

VESSEL FORM: Bowl with four lip tabs (25 mm in width) 
NON-PLASTICS AND PASTE: grog

RIM AND LIP FORM: Direct and interior thickened rim and rounded lip

CORE COLOR: $\mathrm{F}$ (fired in a reducing environment and cooled in the open air)

INTERIOR SURFACE COLOR: red

EXTERIOR SURFACE COLOR: red

WALL THICKNESS (IN MM): rim, $7.9 \mathrm{~mm}$; body, $7.5 \mathrm{~mm}$

INTERIOR SURFACE TREATMENT: smoothed

EXTERIOR SURFACE TREATMENT: burnished

HEIGHT (IN CM): 8.3

ORIFICE DIAMETER (IN CM): 19.7

DIAMETER AT BOTTOM OF RIM OR NECK (IN CM): N/A

BASE DIAMETER (IN CM) AND SHAPE OF BASE: 8.2., circular and flat

ESTIMATED VOLUME (IN LITERS): 0.7

DECORATION (INCLUDING MOTIF AND ELEMENTS WHEN APPARENT): The interior and exterior vessel surfaces have a red slip.

PIGMENT USE AND LOCATION ON VESSEL: none

TYPE AND VARIETY (IF KNOWN): Sanders Slipped

\section{SUMMARY AND CONCLUSIONS}

The Caddo ceramic vessels from these seven sites in the upper Sabine River basin in Wood County comprise a relatively diverse vessel assemblage from burial features dating to the Middle and Late Caddo periods. The Middle Caddo period vessels from these Wood County sites include a grog-tempered Sanders Slipped bowl from the A. C. Gibson site (41WD1), as well as a grog-tempered plain jar with lip tabs, a grogtempered Maxey Noded Redware bottle and a plain bowl with lip tabs from the Mattie Dial site (41WD5), as well as a Sanders Slipped bowl from 41WD117. The 17 grog-tempered vessels from the H. D. Spigner site (41WD4) also are from Middle Caddo period funerary contexts. These vessels include an assortment of plain bowls $(n=3)$, bottles $(n=1)$, carinated bowls $(n=1)$, and compound bowls $(n=2)$, as well as Sanders Engraved carinated bowls ( $n=3)$, a tool punctated jar, an appliqued bowl, Canton Incised jars $(n=2)$, and a Bullard Brushed jar. Two bottles in the H. D. Spigner site vessel assemblage have distinctive but unidentified engraved decorative elements featuring hatched triangles and curvilinear lines or large pendant triangles with hatched corners and hooked arm vertical scrolls; this latter vessel resembles Wilder Engraved, var. unspecified, with the exception that there are engraved pendant triangles on the hooked arm scrolls.

The two La Rue Neck Banded grog-tempered ceramic vessels from the B. F. Cathey site (41WD14) are from a Late Caddo period Titus phase burial. The grog-tempered vessels from the J. H. Baker site (41WD33) are also from a Titus phase burial: they include a Wilder Engraved, var. unspecified bottle, a Taylor Engraved 
bottle, a Ripley Engraved, var. Carpenter carinated bowl, and a red-slipped bottle with two columns of appliqued ridges on the vessel body. The 26 ceramic vessels from the J. H. Reese site (41WD2) are from three Titus phase burials excavated in 1930 by UT: 12 vessels with Burial 1, eight vessels in Burial 2, and four vessels in Burial 3; two other vessels were apparently purchased from the landowner. About 96 percent of the vessels from the J. H. Reese site are grog-tempered; one jar has both grog and burned bone temper. The fine ware vessels from the site include Ripley Engraved, var. Galt carinated bowls ( $\mathrm{n}=6)$, Ripley Engraved, var. Gandy carinated bowls $(\mathrm{n}=4)$, a Ripley Engraved, var. McKinney carinated bowl $(\mathrm{n}=1)$, and a Ripley Engraved, var. unspecified carinated bowl, as well as a Taylor Engraved bottle in Burial 1 and a Wilder Engraved, var. unspecified bottle in Burial 2. A Wilder Engraved, var. unspecified jar (with loop handles) is among the funerary offerings in Burial 3, and a similar engraved jar is one of the two purchased vessels. The last fine ware vessel in the assemblage is a Turner Engraved, var. Turner compound bowl. One vessel in Burial 2 has a hatched and scalloped engraved design, and a carinated bowl in the same burial had diagonal engraved lines with large cross-hatched pendant triangles. Utility wares in the assemblage are represented by La Rue Neck Banded jars ( $n=5)$ and a Mockingbird Punctated jar. There is also a single plain carinated bowl in the vessel assemblage.

\section{ACKNOWLEDGMENTS}

Lance Trask and Sandra Hannum prepared the figures for this article. Thanks also to Marybeth Tomka of the Texas Archeological Research Laboratory at The University of Texas at Austin for access to the vessel collection for documentation purposes.

\section{REFERENCES CITED}

Cast, R., T. K. Perttula, B. Gonzalez, and B. Nelson

2006 Documentation of Caddo Ceramic Vessels from 41WD60, Wood County, Texas. Historic Preservation Program, Caddo Nation of Oklahoma, Binger, Oklahoma.

Jackson, A. T.

1934 Notes on Work Done Gibson Place. MS on file, Texas Archeological Research Laboratory, The University of Texas at Austin.

Perttula, T. K.

2005 The M. W. Burks Site (41WD52), A Late Caddo Hamlet in Wood County, Texas. Journal of Northeast Texas Archaeology 23:1-27.

Perttula, T. K., B. Nelson, and M. Walters

2012 Caddo Archaeology at the Henry Spencer Site (41UR315) in the Little Cypress Creek Basin of East Texas. Special Publication No. 20. Friends of Northeast Texas Archaeology, Pittsburg and Austin.

Perttula, T. K., B. D. Skiles, M. B. Collins, M. C. Trachte, and F. Valdez, Jr.

1986 "This Everlasting Sand Bed": Cultural Resources Investigations at the Two Big Sandy Project, Wood and Upshur Counties, Texas. Reports of Investigations No. 52. Prewitt and Associates, Inc., Austin.

Perttula, T. K., R. R. Turbeville, and B. D. Skiles

1987 New Thermoluminescence and Radiocarbon Dates from the Upper Sabine River Basin, East Texas. Texas Archeology 31(2):7-9.

Perttula, T. K., M. Walters, R. Cast, B. Gonzalez, and B. Nelson

2007 Documentation of Funerary Offerings from a Prehistoric Caddo Burial at Site 41WD244, Wood County, Texas. Caddo Nation of Oklahoma and Archeological \& Environmental Consultants, LLC, Binger and Austin. 
Reese, M. M.

1931 Report on Work Done on H. D. Spigner (Negro) Farm, Wood County, Texas, 5 Miles North of Quitman, First Week of May, 1931. MS on file, Texas Archeological Research Laboratory, The University of Texas at Austin.

Walters, M., with contributions by T. Middlebrook and T. K. Perttula

2010 Redwine or Pie-Crust Mode Forms in East Texas Caddo Ceramics and comparisons with Sprocket-Rims of Southwest Arkansas. Caddo Archeology Journal 20:77-128.

Wilson, A. M. and A. T. Jackson

1930 Field Notes: Work Done at Indian Sites, Wood County, Texas. MS on file, Texas Archeological Research Laboratory, The University of Texas at Austin. 